\title{
The Confluence of Sex Hormones and Aging on Immunity
}

\author{
Melanie R. Gubbels Bupp ${ }^{1 *}$, Tanvi Potluri², Ashley L. Fink ${ }^{2}$ and Sabra L. Klein ${ }^{2}$ \\ ${ }^{1}$ Department of Biology, Randolph-Macon College, Ashland, VA, United States, ${ }^{2}$ W. Harry Feinstone Department of \\ Molecular Microbiology and Immunology, Bloomberg School of Public Health, Johns Hopkins University, Baltimore, \\ MD, United States
}

OPEN ACCESS

Edited by:

Virginia Rider,

Pittsburg State University,

United States

Reviewed by:

Piergiuseppe De Berardinis, Istituto di biochimica delle proteine (IBP), Italy Paola Italiani,

Consiglio Nazionale Delle Ricerche (CNR), Italy

*Correspondence:

Melanie R. Gubbels Bupp melaniegubbelsbupp@rmc.edu

Specialty section: This article was submitted to Cytokines and Soluble Mediators in Immunity, a section of the journal Frontiers in Immunology

Received: 19 March 2018 Accepted: 22 May 2018

Published: 04 June 2018

Citation:

Gubbels Bupp MR, Potluri T,

Fink AL and Klein SL (2018)

The Confluence of Sex Hormones and Aging on Immunity.

Front. Immunol. 9:1269. doi: 10.3389/fimmu.2018.01269
The immune systems of post-pubescent males and females differ significantly with profound consequences to health and disease. In many cases, sex-specific differences in the immune responses of young adults are also apparent in aged men and women. Moreover, as in young adults, aged women develop several late-adult onset autoimmune conditions more frequently than do men, while aged men continue to develop many cancers to a greater extent than aged women. However, sex differences in the immune systems of aged individuals have not been extensively investigated and data addressing the effectiveness of vaccinations and immunotherapies in aged men and women are scarce. In this review, we evaluate age- and sex hormone-related changes to innate and adaptive immunity, with consideration about how this impacts age- and sex-associated changes in the incidence and pathogenesis of autoimmunity and cancer as well as the efficacy of vaccination and cancer immunotherapy. We conclude that future preclinical and clinical studies should consider age and sex to better understand the ways in which these characteristics intersect with immune function and the resulting consequences for autoimmunity, cancer, and therapeutic interventions.

Keywords: sex, sex hormones, immunity, autoimmunity, cancer, vaccines, immunotherapy, checkpoint blockade

\section{INTRODUCTION}

In developed countries, the population is aging, with the number of people over the age of 65 doubling in size from 2012 to 2050 (1). In developed and even developing countries, lifespan is longer for women than men $(2,3)$. Both sex (i.e., biological differences between males and females) and gender (i.e., social or cultural norms that define masculine and feminine) contribute to male-female differences in mortality rates among individuals 65 years and older. Why and how the sexes differ in the incidence and progression of immune-related diseases that are either specific to advanced age or that worsen with age, such as particular infections, autoimmune disease, and cancer, has not been well studied.

Aging is associated with the development of chronic inflammation and a general reduction in immune function. The effect of sex on immune function during the aging process has not been well studied. But, some studies indicate that the innate immune system of aged females may be more inflammation-prone when compared with aged males. However, aging of the adaptive immune system may occur at a faster rate in men, when compared with women. Several diseases that are associated with age are also sensitive to changes in the immune system. Therefore, herein, we will discuss the effects of age and sex on the innate and adaptive immune systems and the contribution of sex hormones to these effects. We will also examine the functional consequences of age- and sex-related changes to immunity in the contexts of vaccination, autoimmunity, cancer, and cancer 
immunotherapy. We conclude that sex and age should be considered in future clinical and preclinical studies to improve our understanding and treatment of age-associated diseases.

\section{AGE-RELATED CHANGES IN IMMUNE FUNCTION}

With age, there is a decline in the functioning of the immune system (4) that has, until recently, been assumed to occur equally in males and females. "Inflammaging," as defined by aberrant chronic low-grade inflammatory responses, is one of the most well-characterized attributes of an aging immune system (5). The activity of dendritic cell (DC) subsets, macrophages, and neutrophils, each of which are associated with inflammation, also become altered with age (6-9). Inflammatory responses are necessary to clear pathogens and repair tissues; chronicity of inflammatory responses, however, can contribute to tissue damage and disease, especially among aged individuals. Similarly, adaptive immunity becomes less functional with age $(10,11)$. Reductions in lymphopoeisis along with exposure to pathogens throughout the lifespan contribute to reduced numbers of naïve lymphocytes with increased proportions of memory and memory-like lymphocytes that are associated with less robust functional outcomes $(12,13)$. Overall, age-associated changes to the functions of innate and adaptive immune cells (summarized in Figure 1) likely contribute to increased risk of specific autoimmune diseases and cancer, as well as altered vaccine and cancer immunotherapy efficacy.

\section{Age-Related Changes in Innate Immunity}

Aging is associated with the secretion of pro-inflammatory cytokines, such as TNF, IL- 6 , and IL-1 $\beta$, the cellular source of which has not yet been clearly identified (14). Innate immune cells, including DCs, neutrophils, and macrophages, become less functional and, paradoxically, more inflammatory with age. It has been difficult to determine whether systemic inflammation causes innate cell dysfunction or vice versa. Recent evidence discussed below suggests that inflammaging may alter the development and signaling potential of innate cells, contributing to inflammation in the absence of infection and, at the same time, a reduced ability to clear infections (15-17). Together, the elevated levels of inflammatory cytokines and diminished ability to resolve infections or local inflammation likely contribute to less functional innate responses to vaccination and increased risk of certain autoimmune diseases.

The number and proportion of plasmacytoid DCs declines during healthy aging, while frailty appears to be associated with reduced numbers of conventional DCs (8). Regardless of their number, conventional DCs from aged mice and humans migrate, phagocytose, express costimulatory molecules, secrete cytokines, and prime $\mathrm{T}$ cells poorly in response to exogenous antigens when compared with DCs from young conspecifics $(6,18-32)$. At least some of these defects appear to be cell intrinsic and related to the altered expression of toll-like receptors (TLRs) and dysregulated downstream signaling [reviewed in Ref. (33)].

Neutrophils from aged individuals have defects in accurately migrating to inflamed tissues, phagocytosing microbes, producing reactive oxygen species (ROS), and capturing microbes using neutrophil extracellular traps $(9,34-38)$. Like neutrophils, many functions of macrophages are negatively affected by aging including migration, phagocytosis, production of ROS and cytokines, and expression of major histocompatibility complex class II and costimulatory molecules $(15,39-43)$. Studies examining the cytokine response of monocytes isolated from older patients have yielded mixed results, likely due to differences in health status, isolation techniques, assay conditions, and stimuli between studies [reviewed in Ref. (33)]. Some studies have revealed a diminished ability of aged monocytes and macrophages to
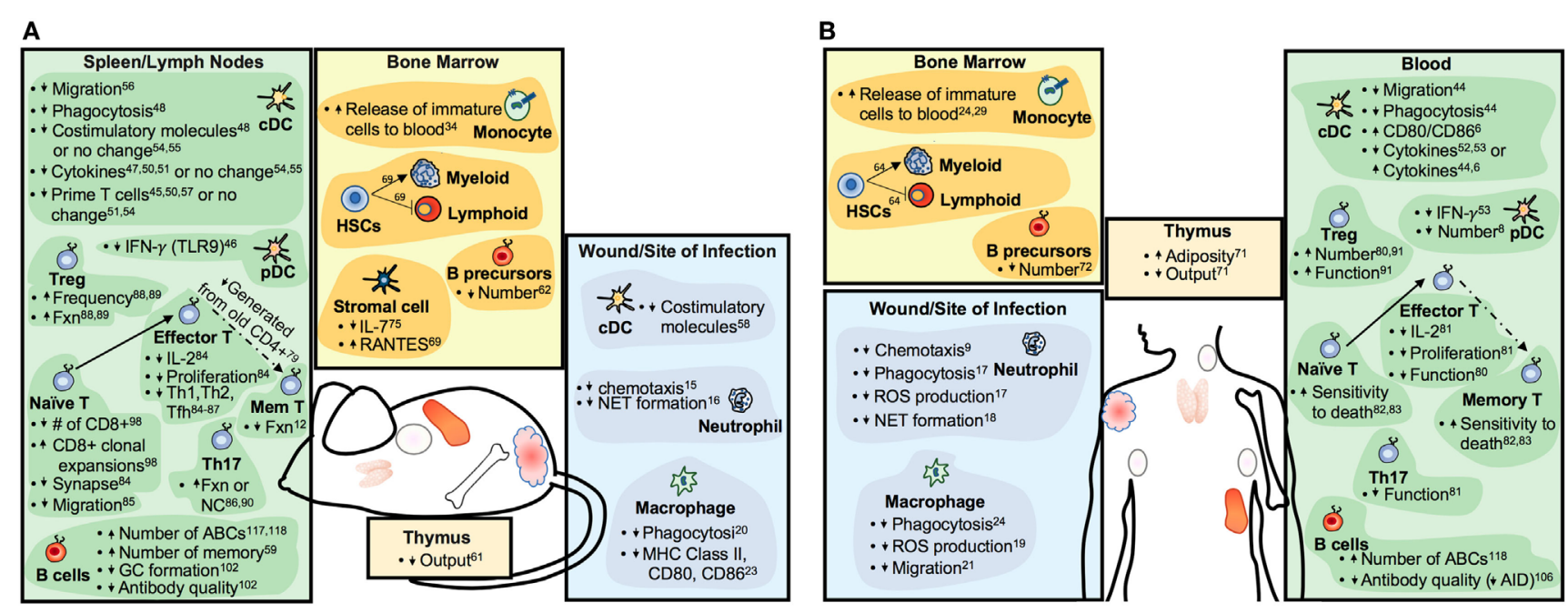

FIGURE 1 | Summary of aging-related changes to the immune systems of mice (A) and humans (B). Increases or decreases in cell numbers or particular functions are indicated by upward- or downward-pointing arrows, respectively. Abbreviations: Fxn, function; GC, germinal center; Mem, memory; ABC, age-associated B cell; NC, no change. 
secrete pro-inflammatory cytokines robustly after exposure to pathogens, LPS, or other TLR ligands (44-50). Chronic exposure to inflammatory cytokines such as IL- 6 and TNF- $\alpha$ and dysregulated expression and/or function of TLRs have been discussed as possible causes $(44,45,48)$.

Several recent reports have suggested that at least in mice, inflammaging may precede and perhaps even cause dysregulation of innate immune cells, which may further contribute to inflammation. For example, aging is also associated with increased proportions of pro-inflammatory monocytes of non-classical and intermediate phenotypes (i.e., $\mathrm{CD} 14^{+} \mathrm{CD} 16^{+}$or $\mathrm{CD} 16^{++}$in humans and $\mathrm{Ly}_{6} \mathrm{C}^{\mathrm{hi}}$ in mice) that are less mature, poorer phagocytes, and may be more prone to secreting pro-inflammatory cytokines at baseline and in response to stimuli $(15-17,47,51)$. In mice, aged Ly6C $\mathrm{C}^{\text {hi }}$ monocytes both contribute to age-associated inflammation and are impaired by the inflammation with negative consequences for bacterial clearance (16). Circumstantial evidence indicates that in humans, premature migration of intermediate phenotype monocytes $\left(\mathrm{CD} 14^{++} \mathrm{CD} 16^{+}\right)$is driven by TNF- $\alpha$-mediated upregulation of CCR2, as also occurs in mice (16), and may contribute to worsened disease outcomes in rheumatoid arthritis patients $(52,53)$.

Additional age-related changes to monocyte function may contribute to increased susceptibility to infection concomitant with a reduced ability to resolve inflammation. For example, the production of specialized pro-resolving mediators, including lipid signaling molecules produced by macrophages and monocytes, is reduced in aged mice and is associated with delayed resolution of acute inflammation (54). In addition, aged macrophages isolated from mice and humans phagocytose infectious agents and apoptotic cells less efficiently than young macrophages $(15,40,55-59)$. The phagocytosis of infectious agents and apoptotic cells by macrophages is important for resolution of inflammation and restoration of tissue integrity, which is reduced with aging.

\section{Age-Related Changes in Adaptive Immunity}

Aging is accompanied by a decline in the production of new lymphocytes as well as increased expansion and survival of antigenspecific memory lymphocytes in mice and humans (60-72). Despite reduced lymphopoeisis (73-76), the overall number of peripheral lymphocytes is maintained in aged mice (11) and humans [reviewed in Ref. (77)], with the exception of peripheral B cell numbers being reduced in older humans $(78,79)$. The diminished functionality of older adaptive cells may be related to age-associated changes in lymphocyte development.

The ability of aged $\mathrm{T}$ cells to proliferate robustly, differentiate appropriately, and generate memory is generally diminished $(10,12,13,80-85)$. However, all $\mathrm{T}$ cell functions are not impaired by aging. $\mathrm{T}$ regulatory $\left(\mathrm{T}_{\text {reg }}\right)$ and, in some cases, $\mathrm{T}$ helper 17 , cells increase in number and/or function with age (81, 85-93). It was recently proposed that naive $\mathrm{T}$ cells produced in neonates form a long-lived, self-renewing population of "incumbent" naïve T cells that are resistant to replacement by $\mathrm{T}$ cells produced after the neonatal period (94). It is conceivable that accumulated damage in these long-lived incumbents may contribute to reduced naive $\mathrm{T}$ cell function with age. In addition, accelerated homeostatic proliferation, as may be more likely to occur in aged individuals $(95,96)$, is associated with the selection of autoreactive $\mathrm{T}$ cells, at least in mice (97-99) and may also affect overall $\mathrm{T}$ cell functionality.

Changes in aged naïve T cell function likely contribute to defective memory generation and also partially explain the observation that antibodies elicited from older mice and humans are less protective compared with those from the young individuals (100-106), even though serum IgG levels increase with age in both mice and humans $(107,108)$. In addition, aged B cells demonstrate intrinsic defects in germinal center formation, class switch recombination, and somatic hypermutation (109-112). Aged B cells from mice and humans do not sufficiently upregulate expression of activation-induced cytidine deaminase (AID, the enzyme required for class switch recombination and somatic hypermutation) due to diminished levels of the necessary transcription factor $(107,110,113,114)$. With age, there are also more long-lived antigen-experienced $\mathrm{B}$ cells, including age-associated B cells (ABCs) $(60,115-120)$. ABCs are responsive to TLR7 and 9 ligands but less so to $\mathrm{T}$ cell-dependent signals and have been hypothesized to be generated by nucleic acid-containing antigens during inflammation $(118,121)$.

\section{SEX DIFFERENCES IN AGE-RELATED CHANGES IN IMMUNE FUNCTION}

Both innate and adaptive immune responses differ between males and females at young and advanced ages (summarized in Table 1). Most published studies of immune system differences between the sexes utilize young adults and do not address whether sex differences in immune function change with aging. Overall, the available data indicate that young adult females demonstrate a more reactive, inflammatory profile when compared with young adult males. A clear consensus has not emerged regarding whether these sex differences are maintained during advanced age, but the immune systems of aged women on hormone replacement therapy (HRT) and monocytes isolated from aged women, regardless of HRT status, appear to remain skewed toward an inflammatory phenotype (16, 122-124). The currently available data also indicate that the adaptive immune response of aged women may be preserved to a greater extent than in aged men. These studies are discussed in more detail below.

\section{Sex Differences in Age-Related Changes to Innate Immunity}

As mentioned above, at least among young adults, innate immune responses differ between the sexes. Using murine model systems, it has been shown that the activity of pattern-recognition receptors, production of inflammatory proteins (e.g., IFN- $\alpha$, IFN- $\gamma$, and TNF- $\alpha$ ), activity of macrophages, including antigen presentation and phagocytosis is higher in females than males (132-138). Studies evaluating innate immune system differences between the sexes are scarce. But, at least one small study demonstrated that aged females display elevated concentrations of inflammatory proteins compared with males, as also occurs in young men and women (139). Several cytokines show differential 
TABLE 1 | Sex differences in innate and adaptive immune responses in young and aged individuals.

\begin{tabular}{|c|c|c|c|c|c|c|c|}
\hline & Dendritic cells & $\begin{array}{l}\text { Monocytes and } \\
\text { macrophages }\end{array}$ & Granulocytes & $\int_{\text {Innate lymphoid cells }}$ & Natural killer cells & $\begin{array}{l}\text { रे } \\
\text { Y cells }\end{array}$ & T cells \\
\hline \multirow[t]{5}{*}{ Young adults } & $\begin{array}{l}\text { }>0 \\
\text { TLR7 activity (H) } \\
\text { Type } 1 \text { IFN activity }(H)\end{array}$ & $\begin{array}{l}q>0 \\
\text { Activation (M) } \\
\text { Phagocytic capacity (M) } \\
\text { IL-10 production (M) }\end{array}$ & $\begin{array}{l}q>0 \\
\text { Phagocytic capacity (M) } \\
\text { Neutrophil count (M) } \\
\text { Nitric Oxide production } \\
\text { post stimulation (H, R, M) }\end{array}$ & $\begin{array}{l}\text { }>0 \\
\text { Type } 2 \text { cytokine levels } \\
\text { upon stimulation }(\mathrm{M})\end{array}$ & & $\begin{array}{l}\uparrow>\sigma^{\star} \\
\text { B cell numbers }(H, M) \\
\text { Antibody production }(H, M) \\
\% \text { switched memory B } \\
\text { cells }(H)\end{array}$ & $\begin{array}{l}q>0^{+} \\
\mathrm{CD} 4^{+} \mathrm{T} \text { cell count }(\mathrm{H}, \mathrm{M}) \\
\mathrm{CD} 4^{+} / \mathrm{CD} 8^{+} \mathrm{T} \text { cell ratio }(\mathrm{H}) \\
\text { Activated } T \text { cell count }(\mathrm{M})\end{array}$ \\
\hline & & M2 polarization ( $\mathrm{M}$ ) & & & & & $\begin{array}{l}\text { T cell proliferative capacity }(\mathrm{M}) \\
\text { Cytotoxic T cell activity }(\mathrm{H})\end{array}$ \\
\hline & $\begin{array}{l}o^{\star}>\uparrow \\
\mathrm{IL}-10 \text { production }(\mathrm{R}, \mathrm{H})\end{array}$ & $\begin{array}{l}0>\uparrow \\
\text { TLR4 expression (M) }\end{array}$ & $0>9$ & $0>9$ & $\begin{array}{l}0>\uparrow \\
\text { NK cell activity }(R)\end{array}$ & & \\
\hline & & $\begin{array}{l}\text { Pro-inflammatory cytokine } \\
\text { production (M) }\end{array}$ & $\begin{array}{l}\text { Neutrophil attractant } \\
\text { chemokines (R) }\end{array}$ & Type 2 ILC count (H) & $q=0^{+}$ & & $\mathrm{CD} 8^{+} \mathrm{T}$ cell count $(\mathrm{M})$ \\
\hline & & M1 polarization (M) & TLR9 expression (M) & $\begin{array}{l}\text { IL-13 production upon } \\
\text { stimulation (M) }\end{array}$ & NK cell count $(H)$ & & $T_{\text {reg }}$ count $(M)$ \\
\hline \multirow[t]{2}{*}{ Aged adults } & $\begin{array}{l}q>0 \\
\text { Nitric oxide synthesis }(\mathrm{H}) \\
\text { Mammalian family of mitogen- } \\
\text { activated protein kinases } \\
(\text { MAPK) signaling }(H, M)\end{array}$ & $\begin{array}{l}\text { १> } \\
\text { CD62L, CD115 (H) } \\
\text { expression }\end{array}$ & & & $\begin{array}{l}\text { }>0 \\
\text { NK cytotoxicity }(\mathrm{H}) \\
\text { Immunosurveillance }(\mathrm{H})\end{array}$ & $\begin{array}{l}q>0 \\
\text { Antibody production }(H) \\
\text { Age-associated B cell } \\
\text { count }(H, M)\end{array}$ & 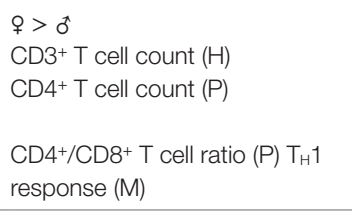 \\
\hline & IL-15 production $(\mathrm{H})$ & $\begin{array}{l} \\
\text { o > } \\
\text { CD38 expression (H) } \\
\text { Non-classical monocyte } \\
\text { count }(\mathrm{H})\end{array}$ & ND & ND & & & $\begin{array}{l}T_{H} 1 \text { response }(M) \\
\text { Naïve } C D 8^{+} T \text { effector memory } \\
\text { cells }(p) \\
T \text { cell proliferative capacity }(H, P) \\
\overbrace{}^{\star}>\uparrow \\
C D 8^{+} T \text { cell count }(P)\end{array}$ \\
\hline
\end{tabular}

Data are from studies of mice $(M)$, rats $(R)$, non-human primates $(P)$, and humans $(H)(125-131)$.

ND, not determined. 
levels in circulation between the sexes. For example, IL-15 is an important homeostatic cytokine in T cells, NK cell, and memory responses and is significantly upregulated in aged females when compared with age-matched males $(122,123)$. However, upon exclusion of individuals on HRT, such differences between sexes were no longer significant (122). After menopause, there is a significant increase in IL-1, IL-6, and TNF $\alpha$, and reduction in IFN $\gamma$ in women $(140,141)$. Testosterone has an immunosuppressive effect on inflammatory cytokine production and its decline with aging is associated with an increase in serum soluble IL-6 receptor (142). Monocyte and leukocyte subpopulations in aged males and females express different levels of receptors; males show higher CD38 expression, whereas females show higher CD62L and CD115 expression, indicating differences in their activation profiles and memory phenotypes (124). Sex differences among monocyte subsets have also been reported in aged individuals. Aged females have a higher proportion of intermediate $\left(\mathrm{CD} 14^{\text {hi }} \mathrm{CD} 16^{\text {low }}\right)$ monocytes than similarly aged males, which have been shown to exhibit pro-inflammatory tendencies, as mentioned above $(16,124)$. Finally, NK cells in older women are superior at cancer immunosurveillance when compared with cells in older men. CD56 ${ }^{\mathrm{dim}}$ NK cells are more cytotoxic and more responsive to leukemic cells in aged females compared with aged males, which may explain the higher incidences of cancer in aged men compared with women in populations (143).

\section{Sex Differences in Age-Related Changes to Adaptive Immunity}

Both humoral and cell-mediated immune responses to antigenic stimulation, vaccination, and infection are typically higher among females than males (135). Females also typically demonstrate higher basal levels of immunoglobulin (144) and higher antibody responses to viruses and vaccine antigens than males at any age (145-147). Among humans, absolute $\mathrm{CD}^{+} \mathrm{T}$ cell counts, frequencies of $\mathrm{CD} 44^{+} \mathrm{T}$ cells, helper $\mathrm{T}$ cell type 1 responses, and the ratio of $\mathrm{CD}^{+}: \mathrm{CD}^{+} \mathrm{T}$ cells are all lower in men when compared with women (148-151).

As already mentioned, sex or gender has not traditionally been considered when evaluating age-related changes to the adaptive immune system [reviewed in Ref. (14)]. However, several groups have reported that in some ways, aging occurs at an accelerated rate in males when compared with females. For example, aged males experience a more dramatic decrease in total numbers of $\mathrm{T}$ and $\mathrm{B}$ cells and a larger increase in senescent $\mathrm{CD} 8^{+} \mathrm{T}$ effector memory cells that re-express the naïve marker CD45 RA ( $\mathrm{T}_{\mathrm{EMRA}}$ ) when compared with females $(14,150,152-154)$. In addition, a greater proportion of aged males than females demonstrate an inverted CD4:CD8 $\mathrm{T}$ cell ratio, an age-related phenotype that is also associated with decreased levels of $\mathrm{CD} 19^{+} \mathrm{B}$ cells and CD ${ }^{+} \mathrm{CD} 28^{-}$senescent $\mathrm{T}$ cells (152). Also, the capacity of T cells to proliferate is preserved to a greater extent in women than men throughout the aging process (154), which may be an important consideration for infectious diseases and related interventions. On the other hand, transcriptional analyses of peripheral blood mononuclear cells from aged males and females revealed several pro-inflammatory pathways, including $\mathrm{NF}-\kappa \mathrm{B}$ signaling, $\mathrm{NO}$ synthesis, and p38 MAPK signaling, that are reduced to a greater extent in aged females than aged males (123). Moreover, aged females have greater numbers of ABCs than young females and males of all ages $(118,119)$.

\section{THE IMPACT OF SEX HORMONES ON AGE-RELATED CHANGES IN IMMUNE RESPONSES}

Immunological differences between males and females can arise from diverse mechanistic causes, including genetic, hormonal, and even microbiome differences between the sexes. Partly because of the ease of measuring and manipulating, sex steroids, particularly testosterone, estradiol, and progesterone, have been most well characterized as mediators of sex differences in immune responses and are the focus of this review. Sex steroids affect immune function by binding to specific hormone receptors expressed in diverse immune cells (155). With age, the hormonal milieu of females and even males changes, with an overall decline in concentrations of estrogens and progesterone in females and testosterone in males (156-158). We hypothesize that the changes in sex steroid concentrations and sex steroid receptor signaling with age may contribute to age-associated dysregulation of immune function (159). Although this has been considered in females through the comparison of pre- and post-menopausal women, few studies have considered hormonal changes in men as playing a role in age-associated changes in immune responses. Among women, with menopause, numbers of $\mathrm{B}$ and $\mathrm{T}$ cells are reduced and concentrations of IL-1 $\beta$, IL- 6 , and TNF- $\alpha$ are significantly increased $(141,160,161)$. Treatment of post-menopausal females with hormone replacement therapies that contain formulations of estrogen affects immune function by increasing circulating numbers of $B$ cells and reducing baseline concentrations of proinflammatory cytokines when compared with post-menopausal females not on HRT $(140,161)$. Whether testosterone replacement therapy affects immune responses in aged human males has not been reported. In non-human primates, aged male rhesus macaques have lower frequencies of naïve $\mathrm{CD} 4^{+}$and $\mathrm{CD} 8^{+} \mathrm{T}$ cells than young males, with supplementation of androgens in aged male resulting in increased numbers of naïve $\mathrm{T}$ cells presumably by increasing thymic output (162). Whether treatment of aged individuals with hormone replacement therapies affects the outcome of vaccines or immunotherapies in either females or males has not been reported.

Studies in mice and humans have shown that the diversity and richness of intestinal microbiota differs between males and females after puberty, presumably due testosterone, but not estrogen (163-168). Moreover, in mice, exposure to specific microbiota at early ages also results in elevated levels of testosterone (164). Thus, testosterone appears to influence the composition of the gut microbiome and, in a positive feedback loop, specific microbes elevate testosterone levels (164). Sex-specific enrichment for particular microbes is likely to have significant influence on sex-specific immune function since particular commensals and their metabolites can dramatically modify host innate and adaptive immune function [reviewed in Ref. (169)] with serious 
consequences for autoimmunity, vaccine efficacy, cancer, and cancer immunotherapy [reviewed in Ref. $(170,171)]$. The composition and richness of commensal microbiota is sensitive to many environmental factors as well, including diet. Importantly, dietary effects on the relative abundance of specific microbial taxa also differ by sex in humans and, to a lesser extent, in mice (172). Sex-specific differences in microbial composition and richness have also been reported in humans over the age of 60 and aged mice $(163,165,166,173)$.

\section{FUNCTIONAL SIGNIFICANCE OF SEX DIFFERENCES IN IMMUNE RESPONSES AMONG AGED INDIVIDUALS}

\section{Vaccine Responses}

In aged individuals, sex differences in antibody responses to vaccines are less consistent and depend on the vaccine antigen. The influence of sex and age has been most well studied for inactivated influenza virus vaccines as they are administered annually. For example, among individuals 65+ years of age, hemagglutinin inhibition antibody titers to both the standard and high dose seasonal trivalent inactivated influenza (TIV) vaccine are significantly higher in aged females when compared with males (174). Because influenza virus vaccines are available on an annual basis, a greater number of exposures (i.e., the behavioral act of seeking out vaccination) combined with the slower decline in immunity that occurs in aged females (see above) may contribute to sex differences in the antibody response to the TIV vaccine. By contrast, aged males have higher antibody responses to the tetanus diphtheria and pertussis ( $\mathrm{Td} /$ Tdap) vaccines as well as the 7 -valent and 23 -valent pneumococcal vaccines (175-179). There is an insufficient number of studies from which to draw conclusions to understand why sex differences in vaccine-induced antibody responses are higher in aged females than males for a viral vaccine (i.e., the TIV vaccine), but lower in females than males for bacterial vaccines (i.e., the $\mathrm{Td}$ /Tdap and pneumococcal vaccines). If more vaccine studies were designed with a priori hypotheses about sex differences in vaccine-induced immunity, then we could begin to understand discrepancies in the findings following exposure to differential vaccine antigens.

Adverse reactions to vaccines, which are typically mild to moderate, can include both local (i.e., at the site of vaccination) and systemic reactions. Adverse reactions are reported by aged women more than their male counterparts in response to the seasonal and pandemic influenza vaccines (180-188), the pneumococcal vaccines $(189,190)$, the herpes zoster vaccine (191), or the tetanus and pertussis vaccines (192-194). While the types of adverse reactions experienced by aged males and females are typically similar, the proportion of females reporting redness, swelling, and injection site pain locally as well as headache, fever, chills, joint or muscle pain, headache, back and abdominal pain, or hypersensitivity reactions systemically is often greater than males. The prevailing hypothesis for differences in adverse reactions among aged males and females is that this reflects a gender-based reporting bias.

The efficacy of a vaccine is measured by the percent reduction in disease incidence in a vaccinated population (195). Sexspecific differences in vaccine efficacy are rarely considered, with most data coming from studies of influenza vaccines. Vaccine efficacy, which is defined by hospitalization and mortality rates post-vaccination, is lower in aged females than males, at least for the influenza vaccine (196-200). For other vaccines that are not administered annually, including the pneumococcal and herpes zoster vaccines, there are considerably less data. Overall, the efficacy both the herpes zoster and pneumococcal vaccines tends to be higher in aged females than their male counterparts (191, 201, 202).

\section{Autoimmunity}

Most autoimmune patients are diagnosed between the ages of 20 and 60 years (203). For those whose autoimmune disease develops later, the disease tends to be milder and more easily controlled (203). Women are disproportionately affected by autoimmune disease, and this holds true for several autoimmune diseases with late-adult onset as well, including rheumatoid arthritis, polymyalgia rheumatica, and giant cell arteritis (Table 2). Regardless of the age of onset, the cellular and molecular basis of autoimmunity is complicated and distinct for each specific disease [reviewed

TABLE 2 | The female-to-male patient ratio for select mid-adult and late-adult onset autoimmune diseases.

\begin{tabular}{|c|c|c|c|c|}
\hline Autoimmune disease & Autoimmune target & Mean age of onset (range) years & Female:male ratio & Reference \\
\hline \multicolumn{5}{|l|}{ Mid-adult onset } \\
\hline Multiple sclerosis & Myelin sheath & $37(25-45)$ & $1.8: 1$ & $(205)$ \\
\hline Myasthenia gravis & Neuromuscular junction & 40 & $2.7: 1$ & $(205)$ \\
\hline Systemic lupus erythematosus & Nuclear contents (systemic) & $40(30-50)$ & $9: 1$ & $(205,206)$ \\
\hline Neuromyelitis optica & Optic nerve/spinal cord & $32.6-45.7$ & $\begin{array}{l}2.4: 1 \\
\text { ratio highest after age } 65\end{array}$ & $(207,208)$ \\
\hline Graves' disease & Thyroid & 48 & $7.3: 1$ & $(205)$ \\
\hline Systemic sclerosis & Connective tissue (systemic) & $50(35-65)$ & $11.5: 1$ & $(209)$ \\
\hline \multicolumn{5}{|l|}{ Late-adult onset } \\
\hline $\begin{array}{l}\text { Granulomatosis with polyangiitis (GPA) } \\
\text { (formerly Wegener's granulomatosis) }\end{array}$ & $\begin{array}{l}\text { Cytoplasmic contents of neutrophils } \\
\text { (systemic, vascular) }\end{array}$ & $55(40-70)$ & $\begin{array}{c}1: 1 \\
M>F \text { after age } 70\end{array}$ & $(205)$ \\
\hline Rheumatoid arthritis & Joints & $58(42-74)$ & $3: 1$ & $(210)$ \\
\hline Polymyalgia rheumatica & Selected muscle groups & $70-80$ & 2.3:1 & $(211)$ \\
\hline Giant cell arteritis & Vascular system & $70-80$ & $2.3: 1$ & $(211)$ \\
\hline
\end{tabular}


in Ref. (204)]. Here, we focus on the impact of age and sex on autoimmune conditions with late onset.

Although several theories have been proposed to explain sex differences in the cellular and molecular basis of aging [reviewed in Ref. (212)], perhaps most relevant to the sex-specific development of autoimmunity in the aged is that estrogen upregulates the activity of several antioxidant systems $(213,214)$. Dramatic loss of estrogen (such as during menopause) could be expected to result in increased cell death due to unchecked ROS-induced DNA damage. Indeed, fewer lymphocytes are detected in the blood of post-menopausal women compared with younger women $(160,215)$ and $T$ cell apoptosis increases after natural or surgical menopause (216). This could especially explain increased female incidence of autoimmune diseases that may occur as a result of lymphopenia-induced homeostatic proliferation in the aged, although more studies are needed to test this hypothesis.

In mice, lymphopenia and the subsequent homeostatic proliferation of lymphocytes has been shown to contribute to the development of autoimmunity in many contexts [reviewed in Ref. (217)]. Certainly, there is an association between autoimmunity and lymphopenia in humans, but a strong case has not been made that lymphopenia is causative, or even occurs prior to, the onset of autoimmunity (218-224). However, evidence gathered by the laboratories of Goronzy et al. support a model whereby accelerated $\mathrm{T}$ cell loss in the aged, either due to telomerase deficiency, disruption to DNA repair responses, or menopause, may be sufficient to enable autoreactive $T$ cells already present in the pool to respond to low-affinity self-antigens in rheumatoid arthritis patients [reviewed in Ref. (225)]. First, there is evidence of accelerated aging, or increased homeostatic proliferation in RA patients. The telomeres of naïve and memory T cells isolated from RA patients are shorter than age-matched controls (226) and $\mathrm{T}$ cell receptor diversity is reduced as well (227). Moreover, $\mathrm{T}$ cells from RA patients are more prone to apoptosis and are less capable of repairing dsDNA breaks (228). Finally, enddifferentiated effector $\mathrm{T}$ cells that may be the consequence of homeostatic proliferation appear to be major participants in late onset autoimmune pathogenesis (229-232).

\section{Cancer}

Sex and age influence cancer incidence and mortality, but the specific effects vary by cancer type. It is widely accepted that the probability of developing cancer increases with age (233). Although few studies have examined cancer incidence in those with very advanced age, it seems that cancer prevalence actually declines for those over the age of $85(234,235)$. There is some evidence to indicate that tumors may also be generally less aggressive in the extremely aged (236). Indeed, breast and prostate cancer patients over the age of 55 are more likely to develop tumors with characteristics associated with favorable treatment and/or survival outcomes $(237,238)$. However, it is not clear that tumors associated with other types of cancer, including bladder cancer, lung cancer, and acute myeloid leukemia, are indolent in older patients (239-242).

Overall, young men generally experience higher rates of cancer incidence and mortality than women (243-245). At advanced ages, men continue to experience higher incidences of most types of cancers, especially colorectal cancer, when compared with women $(245,246)$, but relative cancer mortality rates between older men and women differ by the particular cancer. Mortality differences between men and women diminish with age (especially after the age of 70) for colorectal cancer, stomach cancer, and leukemia (247). However, the male-to-female mortality ratio for brain cancer and myeloma decreases after middle age, but then increases again after the age of 70 (247).

The loss of sex hormones (especially due to menopause in women), age-associated immunosuppression, and chronic inflammation may contribute to sex- and age-specific patterns of cancer incidence and mortality. Indeed, the male preponderance of cancer incidence and mortality before menopause has been at least partially attributed to the protective effect of estrogen (248), presumably due to its ability to enhance immunosurveillance, as well as tissue-specific effects $(249,250)$. Purim et al. suggests that it takes 20-25 years for some cancers (such as colorectal) to develop and since changes in sex-specific incidence ratios for those cancers occur approximately 25 years after menopause, the loss of estrogens at approximately age 55 contributes to increased female cancer incidence after the age of 80 (246). On the other hand, age- and sex-related diminishment of the effectiveness of the immune system may not contribute a great deal to increased cancer incidence in the aged, since the types of cancers observed in the aged are not the same of those observed in immunocompromised patients. HIV-induced immunodeficiency is associated with lymphoma and Kaposi's sarcoma, while most age-related malignancies in the aged are carcinomas (251). Finally, older persons with chronic inflammation may demonstrate increased risk of cancer, as it is clear that inflammation induced by viruses, bacteria, tobacco smoke, and obesity increases cancer risk (252-255). Overall, more studies are certainly warranted to better understand the factors that contribute to cancer incidence and mortality in older men and women.

\section{Cancer Immunotherapy}

Cancer immunotherapy trials typically involve younger patients with no co-morbidities, even though these characteristics are not representative of most cancer patients (256). This is particularly important because the effectiveness and dose of any particular immunotherapy is likely to be affected by age-associated changes in immunity and metabolism (256). In addition, few clinical trials are designed to compare the efficacy and safety of cancer immunotherapies between women and men of any age (257). The currently available data regarding the sex- and age-specific effectiveness of several immunotherapies are discussed below.

Checkpoint blockade therapies in young or middle-aged men and women appear to be beneficial, but the benefits may be stronger in men (258-261). Blockade of PD1/PDL1 with nivolumab was more effective in male melanoma and renal cell carcinoma patients than in female patients $(258,260)$. However, these studies were not designed to compare efficacy in male versus female patients, and the sample size for female patients was small. Preclinical studies of anti-PDL1 treatment revealed that melanoma tumor growth was more robustly reduced in female mice when compared with males (262). Estrogen upregulates PD-1 on $\mathrm{T}_{\text {regs }}$ and $\mathrm{T}_{\text {effs. }}$. The authors speculated that anti-PDL1 treatment 
TABLE 3 | Variables to consider when designing clinical studies related to immunity in the aged.

\begin{tabular}{ll}
\hline & Clinical study considerations \\
\hline Age & Clearly defined age categories \\
& Young: 20 to $\leq 45$ years \\
& Old: $>45$ to $\leq 85$ years \\
& Very old/elderly: $>85$ years \\
\hline Health status & Frailty: three of the five following characteristics: \\
& weight loss, weakened handgrip, exhaustion, \\
& reduced gait speed, and reduced activity \\
& Concentrations of serum inflammatory proteins: \\
& IL-6, TNF- $\alpha$, IL-1 $\beta$, and C-reactive protein \\
\hline Sex hormone status & Time of menopause \\
& Serum concentrations of sex hormones \\
& Hormone replacement therapy
\end{tabular}

was more effective in females because of the greater contribution of PD-1 to $\mathrm{T}_{\text {reg }}$ suppression of antitumor responses in females (262). In addition, as mentioned above, the microbiome varies with age and sex and has recently been shown to significantly influence cancer immunotherapy success. Indeed, recent antibiotic use and the absence of specific microbial taxa correlates with reduced efficacy of PD1/PDL1 blockade and certain immunereliant chemotherapies in both humans and mice [reviewed in Ref. (170, 263)]. Therefore, it is critical to more formally evaluate the effect of cancer immunotherapies in men and women and to assess the suitability of various cancer models for predicting the success of particular immunotherapies in the sexes.

As already mentioned, few clinical immunotherapy trials enroll patients of advanced age and studies that did include older patients reach different conclusions about the efficacy of checkpoint blockade in the aged. Meta-analyses of heterogeneous groups of cancer patients over the age of 65 or 70 treated with immune checkpoint inhibitors (biologicals targeting PD1, PDL1, or CTLA4) compared with similarly aged patients enrolled in the control arm of the studies revealed that checkpoint inhibitors reduced the risk of death by $34-37 \%$ in patients with advanced age $(264,265)$. Moreover, in at least one meta-analysis, the overall survival rate of patients over the age of 65 or 70 and younger patients treated with immune checkpoint inhibitors did not differ (264). However, other studies have reported significantly worse overall survival rates in patients over the age of 75 treated with

\section{REFERENCES}

1. Ortman JM, Velkoff VA, Hogan H. An aging nation: the older population in the United States. Current Population Reports. Washington, DC: U.S. Census Bureau (2014).

2. Lozano R, Naghavi M, Foreman K, Lim S, Shibuya K, Aboyans V, et al. Global and regional mortality from 235 causes of death for 20 age groups in 1990 and 2010: a systematic analysis for the Global Burden of Disease Study 2010. Lancet (2012) 380(9859):2095-128. doi:10.1016/S0140-6736(12)61728-0

3. GBD 2013 Mortality and Causes of Death Collaborators. Global, regional, and national age-sex specific all-cause and cause-specific mortality for 240 causes of death, 1990-2013: a systematic analysis for the Global Burden of Disease Study 2013. Lancet (2015) 385(9963):117-71. doi:10.1016/S0140-6736(14) $61682-2$ checkpoint inhibitors (266). Finally, there is concern that treatment of older cancer patients with checkpoint inhibitors could actually enhance tumor growth, as occurred in one subset of cancer patients (267) or prompt immune-related adverse events, as occurs in mouse models (268).

\section{CONCLUSION}

For most, the aging process is accompanied by alterations in the function of the immune system. Many experience chronic inflammation and a general impairment of immune cell function. The immune systems of young men and women are quite different, and it appears that aging affects the cellular composition and function of the immune system in sex-specific ways as well. This is likely because of pre-existing differences in immunity between men and women as well as differences in how menopause and andropause unfold. Age- and sex-specific changes to immunity may have consequences for late-adult onset autoimmunity and cancer, as well as for the efficacy of vaccinations and cancer immunotherapies. However, our understanding of the ways in which sex and age intersect with immune function and the consequences of this for autoimmunity, cancer, and therapeutic interventions is severely limited by the lack of inclusion of these variables in clinical and preclinical studies. Therefore, preclinical and clinical studies related to vaccination, autoimmunity, and cancer therapies must be powered to detect sex effects, in accordance with the sex and gender equity in research (SAGER) guidelines (269). Age, sex hormone concentrations, hormone replacement therapies, and health status must be considered as well, given the known impact of these variables on immune-related conditions common in the aged (Table 3).

\section{AUTHOR CONTRIBUTIONS}

MB conceived of the idea for this review. MB and SK outlined the content. MB, TP, AF, and SK researched and wrote sections. All authors edited and reviewed the final draft.

\section{FUNDING}

The writing of this review was supported by the NIH/NIAID Center of Excellence in Influenza Research and Surveillance contract HHS N272201400007C (SK).
4. Castelo-Branco C, Soveral I. The immune system and aging: a review. Gynecol Endocrinol (2014) 30(1):16-22. doi:10.3109/09513590.2013.852531

5. Cannizzo ES, Clement CC, Sahu R, Follo C, Santambrogio L. Oxidative stress, inflamm-aging and immunosenescence. J Proteomics (2011) 74(11):2313-23. doi:10.1016/j.jprot.2011.06.005

6. Agrawal A, Tay J, Ton S, Agrawal S, Gupta S. Increased reactivity of dendritic cells from aged subjects to self-antigen, the human DNA. J Immunol (2009) 182(2):1138-45. doi:10.4049/jimmunol.182.2.1138

7. Canan CH, Gokhale NS, Carruthers B, Lafuse WP, Schlesinger LS, Torrelles $\mathrm{JB}$, et al. Characterization of lung inflammation and its impact on macrophage function in aging. J Leukoc Biol (2014) 96(3):473-80. doi:10.1189/ jlb.4A0214-093RR

8. Jing Y, Shaheen E, Drake RR, Chen N, Gravenstein S, Deng Y. Aging is associated with a numerical and functional decline in plasmacytoid dendritic cells, whereas 
myeloid dendritic cells are relatively unaltered in human peripheral blood. Hum Immunol (2009) 70(10):777-84. doi:10.1016/j.humimm.2009.07.005

9. Wenisch C, Patruta S, Daxbock F, Krause R, Horl W. Effect of age on human neutrophil function. J Leukoc Biol (2000) 67(1):40-5. doi:10.1002/jlb.67.1.40

10. Haynes L, Maue AC. Effects of aging on T cell function. Curr Opin Immunol (2009) 21(4):414-7. doi:10.1016/j.coi.2009.05.009

11. Miller JP, Cancro MP. B cells and aging: balancing the homeostatic equation. Exp Gerontol (2007) 42(5):396-9. doi:10.1016/j.exger.2007.01.010

12. Haynes L, Eaton SM, Burns EM, Randall TD, Swain SL. CD4 T cell memory derived from young naive cells functions well into old age, but memory generated from aged naive cells functions poorly. Proc Natl Acad Sci U S A (2003) 100(25):15053-8. doi:10.1073/pnas.2433717100

13. Kang I, Hong MS, Nolasco H, Park SH, Dan JM, Choi JY, et al. Age-associated change in the frequency of memory CD4+ T cells impairs long term CD4+ $\mathrm{T}$ cell responses to influenza vaccine. J Immunol (2004) 173(1):673-81. doi:10.4049/jimmunol.173.1.673

14. Gubbels Bupp MR. Sex, the aging immune system, and chronic disease. Cell Immunol (2015) 294(2):102-10. doi:10.1016/j.cellimm.2015.02.002

15. Hearps AC, Martin GE, Angelovich TA, Cheng WJ, Maisa A, Landay AL, et al. Aging is associated with chronic innate immune activation and dysregulation of monocyte phenotype and function. Aging Cell (2012) 11(5):867-75. doi:10.1111/j.1474-9726.2012.00851.x

16. Puchta A, Naidoo A, Verschoor CP, Loukov D, Thevaranjan N, Mandur TS, et al. TNF drives monocyte dysfunction with age and results in impaired antipneumococcal immunity. PLoS Pathog (2016) 12(1):e1005368. doi:10.1371/ journal.ppat. 1005368

17. Verschoor CP, Johnstone J, Millar J, Parsons R, Lelic A, Loeb M, et al. Alterations to the frequency and function of peripheral blood monocytes and associations with chronic disease in the advanced-age, frail elderly. PLoS One (2014) 9(8):e104522. doi:10.1371/journal.pone.0104522

18. Agrawal A, Agrawal S, Cao JN, Su H, Osann K, Gupta S. Altered innate immune functioning of dendritic cells in elderly humans: a role of phosphoinositide 3-kinase-signaling pathway. J Immunol (2007) 178(11):6912-22. doi:10.4049/jimmunol.178.11.6912

19. Moretto MM, Lawlor EM, Khan IA. Aging mice exhibit a functional defect in mucosal dendritic cell response against an intracellular pathogen. J Immunol (2008) 181(11):7977-84. doi:10.4049/jimmunol.181.11.7977

20. Stout-Delgado HW, Yang X, Walker WE, Tesar BM, Goldstein DR. Aging impairs IFN regulatory factor 7 up-regulation in plasmacytoid dendritic cells during TLR9 activation. J Immunol (2008) 181(10):6747-56. doi:10.4049/ jimmunol.181.10.6747

21. Pereira LF, de Souza AP, Borges TJ, Bonorino C. Impaired in vivo CD4+ $\mathrm{T}$ cell expansion and differentiation in aged mice is not solely due to $\mathrm{T}$ cell defects: decreased stimulation by aged dendritic cells. Mech Ageing Dev (2011) 132(4):187-94. doi:10.1016/j.mad.2011.03.005

22. Li G, Smithey MJ, Rudd BD, Nikolich-Zugich J. Age-associated alterations in CD8alpha+ dendritic cells impair CD8 T-cell expansion in response to an intracellular bacterium. Aging Cell (2012) 11(6):968-77. doi:10.1111/ j.1474-9726.2012.00867.x

23. Chougnet CA, Thacker RI, Shehata HM, Hennies CM, Lehn MA, Lages CS, et al. Loss of phagocytic and antigen cross-presenting capacity in aging dendritic cells is associated with mitochondrial dysfunction. J Immunol (2015) 195(6):2624-32. doi:10.4049/jimmunol.1501006

24. Grolleau-Julius A, Garg MR, Mo R, Stoolman LL, Yung RL. Effect of aging on bone marrow-derived murine CD11c+CD4-CD8alpha- dendritic cell function. J Gerontol A Biol Sci Med Sci (2006) 61(10):1039-47. doi:10.1093/ gerona/61.10.1039

25. Wong CP, Magnusson KR, Ho E. Aging is associated with altered dendritic cells subset distribution and impaired proinflammatory cytokine production. Exp Gerontol (2010) 45(2):163-9. doi:10.1016/j.exger.2009.11.005

26. Qian F, Wang X, Zhang L, Lin A, Zhao H, Fikrig E, et al. Impaired interferon signaling in dendritic cells from older donors infected in vitro with West Nile virus. J Infect Dis (2011) 203(10):1415-24. doi:10.1093/infdis/jir048

27. Panda A, Qian F, Mohanty S, van Duin D, Newman FK, Zhang L, et al. Age-associated decrease in TLR function in primary human dendritic cells predicts influenza vaccine response. JImmunol (2010) 184(5):2518-27. doi:10.4049/jimmunol.0901022

28. Tesar BM, Walker WE, Unternaehrer J, Joshi NS, Chandele A, Haynes L, et al. Murine [corrected] myeloid dendritic cell-dependent toll-like receptor immunity is preserved with aging. Aging Cell (2006) 5(6):473-86. doi:10.1111/j.1474-9726.2006.00245.x

29. Jones SC, Brahmakshatriya V, Huston G, Dibble J, Swain SL. TLR-activated dendritic cells enhance the response of aged naive CD4 T cells via an IL-6dependent mechanism. J Immunol (2010) 185(11):6783-94. doi:10.4049/ jimmunol.0901296

30. Zhao J, Zhao J, Legge K, Perlman S. Age-related increases in $\operatorname{PGD}(2)$ expression impair respiratory DC migration, resulting in diminished $\mathrm{T}$ cell responses upon respiratory virus infection in mice. JClin Invest (2011) 121(12):4921-30. doi:10.1172/JCI59777

31. Grolleau-Julius A, Harning EK, Abernathy LM, Yung RL. Impaired dendritic cell function in aging leads to defective antitumor immunity. Cancer Res (2008) 68(15):6341-9. doi:10.1158/0008-5472.CAN-07-5769

32. Tan SY, Cavanagh LL, d'Advigor W, Shackel N, Fazekas de St Groth B, Weninger W. Phenotype and functions of conventional dendritic cells are not compromised in aged mice. Immunol Cell Biol (2012) 90(7):722-32. doi:10.1038/icb.2011.104

33. Shaw AC, Panda A, Joshi SR, Qian F, Allore HG, Montgomery RR. Dysregulation of human toll-like receptor function in aging. Ageing Res Rev (2011) 10(3):346-53. doi:10.1016/j.arr.2010.10.007

34. Sapey E, Greenwood H, Walton G, Mann E, Love A, Aaronson N, et al. Phosphoinositide 3-kinase inhibition restores neutrophil accuracy in the elderly: toward targeted treatments for immunosenescence. Blood (2014) 123(2):239-48. doi:10.1182/blood-2013-08-519520

35. Brubaker AL, Rendon JL, Ramirez L, Choudhry MA, Kovacs EJ. Reduced neutrophil chemotaxis and infiltration contributes to delayed resolution of cutaneous wound infection with advanced age. JImmunol (2013) 190(4):1746-57. doi:10.4049/jimmunol.1201213

36. Tseng CW, Kyme PA, Arruda A, Ramanujan VK, Tawackoli W, Liu GY. Innate immune dysfunctions in aged mice facilitate the systemic dissemination of methicillin-resistant S. aureus. PLoS One (2012) 7(7):e41454. doi:10.1371/ journal.pone. 0041454

37. Alonso-Fernandez P, Puerto M, Mate I, Ribera JM, de la Fuente M. Neutrophils of centenarians show function levels similar to those of young adults. J Am Geriatr Soc (2008) 56(12):2244-51. doi:10.1111/j.1532-5415.2008. 02018.x

38. Hazeldine J, Harris P, Chapple IL, Grant M, Greenwood H, Livesey A, et al. Impaired neutrophil extracellular trap formation: a novel defect in the innate immune system of aged individuals. Aging Cell (2014) 13(4):690-8. doi:10.1111/acel.12222

39. McLachlan JA, Serkin CD, Morrey-Clark KM, Bakouche O. Immunological functions of aged human monocytes. Pathobiology (1995) 63(3):148-59. doi: $10.1159 / 000163946$

40. De La Fuente M. Changes in the macrophage function with aging. Comp Biochem Physiol A Comp Physiol (1985) 81(4):935-8. doi:10.1016/0300-9629(85) 90933-8

41. Fietta A, Merlini C, De Bernardi PM, Gandola L, Piccioni PD, Grassi C. Non specific immunity in aged healthy subjects and in patients with chronic bronchitis. Aging (Milano) (1993) 5(5):357-61.

42. Plowden J, Renshaw-Hoelscher M, Engleman C, Katz J, Sambhara S. Innate immunity in aging: impact on macrophage function. Aging Cell (2004) 3(4):161-7. doi:10.1111/j.1474-9728.2004.00102.x

43. Herrero C, Marques L, Lloberas J, Celada A. IFN-gamma-dependent transcription of MHC class II IA is impaired in macrophages from aged mice. J Clin Invest (2001) 107(4):485-93. doi:10.1172/JCI11696

44. Boehmer ED, Goral J, Faunce DE, Kovacs EJ. Age-dependent decrease in tolllike receptor 4-mediated proinflammatory cytokine production and mitogenactivated protein kinase expression. J Leukoc Biol (2004) 75(2):342-9. doi:10.1189/jlb.0803389

45. Boehmer ED, Meehan MJ, Cutro BT, Kovacs EJ. Aging negatively skews macrophage TLR2- and TLR4-mediated pro-inflammatory responses without affecting the IL-2-stimulated pathway. Mech Ageing Dev (2005) 126(12):1305-13. doi:10.1016/j.mad.2005.07.009

46. Montgomery RR, Shaw AC. Paradoxical changes in innate immunity in aging: recent progress and new directions. J Leukoc Biol (2015) 98(6):937-43. doi:10.1189/jlb.5MR0315-104R

47. Nyugen J, Agrawal S, Gollapudi S, Gupta S. Impaired functions of peripheral blood monocyte subpopulations in aged humans. J Clin Immunol (2010) 30(6):806-13. doi:10.1007/s10875-010-9448-8 
48. van Duin D, Mohanty S, Thomas V, Ginter S, Montgomery RR, Fikrig E, et al. Age-associated defect in human TLR-1/2 function. J Immunol (2007) 178(2):970-5. doi:10.4049/jimmunol.178.2.970

49. Agius E, Lacy KE, Vukmanovic-Stejic M, Jagger AL, Papageorgiou AP, Hall S, et al. Decreased TNF-alpha synthesis by macrophages restricts cutaneous immunosurveillance by memory CD4+ T cells during aging. J Exp Med (2009) 206(9):1929-40. doi:10.1084/jem.20090896

50. Molony RD, Nguyen JT, Kong Y, Montgomery RR, Shaw AC, Iwasaki A. Aging impairs both primary and secondary RIG-I signaling for interferon induction in human monocytes. Sci Signal (2017) 10(509):eaan2392. doi:10.1126/ scisignal.aan 2392

51. Seidler S, Zimmermann HW, Bartneck M, Trautwein C, Tacke F. Agedependent alterations of monocyte subsets and monocyte-related chemokine pathways in healthy adults. BMC Immunol (2010) 11:30. doi:10.1186/ 1471-2172-11-30

52. Chara L, Sanchez-Atrio A, Perez A, Cuende E, Albarran F, Turrion A, et al. Monocyte populations as markers of response to adalimumab plus MTX in rheumatoid arthritis. Arthritis Res Ther (2012) 14(4):R175. doi:10.1186/ $\operatorname{ar} 3928$

53. Xia L, Lu J, Xiao W. Blockage of TNF-alpha by infliximab reduces CCL2 and CCR2 levels in patients with rheumatoid arthritis. J Investig Med (2011) 59(6):961-3. doi:10.2310/JIM.0b013e31821c0242

54. Arnardottir HH, Dalli J, Colas RA, Shinohara M, Serhan CN. Aging delays resolution of acute inflammation in mice: reprogramming the host response with novel nano-proresolving medicines. J Immunol (2014) 193(8):4235-44. doi:10.4049/jimmunol.1401313

55. Albright JW, Albright JF. Ageing alters the competence of the immune system to control parasitic infection. Immunol Lett (1994) 40(3):279-85. doi:10.1016/0165-2478(94)00066-2

56. Bradley SF, Kauffman CA. Aging and the response to Salmonella infection. Exp Gerontol (1990) 25(1):75-80. doi:10.1016/0531-5565(90)90012-Q

57. Aprahamian T, Takemura Y, Goukassian D, Walsh K. Ageing is associated with diminished apoptotic cell clearance in vivo. Clin Exp Immunol (2008) 152(3):448-55. doi:10.1111/j.1365-2249.2008.03658.x

58. Njie EG, Boelen E, Stassen FR, Steinbusch HW, Borchelt DR, Streit WJ. Ex vivo cultures of microglia from young and aged rodent brain reveal agerelated changes in microglial function. Neurobiol Aging (2012) 33(1):195. e1-12. doi:10.1016/j.neurobiolaging.2010.05.008

59. Swift ME, Burns AL, Gray KL, DiPietro LA. Age-related alterations in the inflammatory response to dermal injury. J Invest Dermatol (2001) 117(5):1027-35. doi:10.1046/j.0022-202x.2001.01539.x

60. Johnson SA, Rozzo SJ, Cambier JC. Aging-dependent exclusion of antigeninexperienced cells from the peripheral B cell repertoire. J Immunol (2002) 168(10):5014-23. doi:10.4049/jimmunol.168.10.5014

61. Riley RL. Impaired B lymphopoiesis in old age: a role for inflammatory B cells? Immunol Res (2013) 57(1-3):361-9. doi:10.1007/s12026-0138444-5

62. Berent-Maoz B, Montecino-Rodriguez E, Dorshkind K. Genetic regulation of thymocyte progenitor aging. Semin Immunol (2012) 24(5):303-8. doi:10.1016/j.smim.2012.04.006

63. Min H, Montecino-Rodriguez E, Dorshkind K. Effects of aging on early B- and T-cell development. Immunol Rev (2005) 205:7-17. doi:10.1111/ j.0105-2896.2005.00263.x

64. Nikolich-Zugich J. Aging of the T cell compartment in mice and humans: from no naive expectations to foggy memories. J Immunol (2014) 193(6):2622-9. doi:10.4049/jimmunol.1401174

65. Geiger H, de Haan G, Florian MC. The ageing haematopoietic stem cell compartment. Nat Rev Immunol (2013) 13(5):376-89. doi:10.1038/nri3433

66. Morrison SJ, Wandycz AM, Akashi K, Globerson A, Weissman IL. The aging of hematopoietic stem cells. Nat Med (1996) 2(9):1011-6. doi:10.1038/ nm1296-1282

67. Sudo K, Ema H, Morita Y, Nakauchi H. Age-associated characteristics of murine hematopoietic stem cells. J Exp Med (2000) 192(9):1273-80. doi:10.1084/jem.192.9.1273

68. Miller JP, Allman D. Linking age-related defects in B lymphopoiesis to the aging of hematopoietic stem cells. Semin Immunol (2005) 17(5):321-9. doi:10.1016/j.smim.2005.05.003

69. Shimazu T, Iida R, Zhang Q, Welner RS, Medina KL, Alberola-Lla J, et al. CD86 is expressed on murine hematopoietic stem cells and denotes lymphopoietic potential. Blood (2012) 119(21):4889-97. doi:10.1182/blood2011-10-388736

70. Ergen AV, Boles NC, Goodell MA. Rantes/Ccl5 influences hematopoietic stem cell subtypes and causes myeloid skewing. Blood (2012) 119(11):2500-9. doi:10.1182/blood-2011-11-391730

71. Labrie JE III, Sah AP, Allman DM, Cancro MP, Gerstein RM. Bone marrow microenvironmental changes underlie reduced RAG-mediated recombination and B cell generation in aged mice. J Exp Med (2004) 200(4):411-23. doi:10.1084/jem.20040845

72. Palmer DB. The effect of age on thymic function. Front Immunol (2013) 4:316. doi:10.3389/fimmu.2013.00316

73. McKenna RW, Washington LT, Aquino DB, Picker LJ, Kroft SH. Immunophenotypic analysis of hematogones (B-lymphocyte precursors) in 662 consecutive bone marrow specimens by 4 -color flow cytometry. Blood (2001) 98(8):2498-507. doi:10.1182/blood.V98.8.2498

74. Rossi MID, Yokota T, Medina KL, Garrett KP, Comp PC, Schipul AH, et al. B lymphopoiesis is active throughout human life, but there are developmental age-related changes. Blood (2003) 101(2):576-84. doi:10.1182/ blood-2002-03-0896

75. Alter-Wolf S, Blomberg BB, Riley RL. Deviation of the B cell pathway in senescent mice is associated with reduced surrogate light chain expression and altered immature B cell generation, phenotype, and light chain expression. J Immunol (2009) 182(1):138-47. doi:10.4049/jimmunol.182.1.138

76. Stephan RP, Reilly CR, Witte PL. Impaired ability of bone marrow stromal cells to support B-lymphopoiesis with age. Blood (1998) 91(1):75-88.

77. Goronzy JJ, Fang F, Cavanagh MM, Qi Q, Weyand CM. Naive T cell maintenance and function in human aging. J Immunol (2015) 194(9):4073-80. doi:10.4049/jimmunol.1500046

78. Weksler ME, Szabo P. The effect of age on the B-cell repertoire. J Clin Immunol (2000) 20(4):240-9. doi:10.1023/A:1006659401385

79. Sansoni P, Cossarizza A, Brianti V, Fagnoni F, Snelli G, Monti D, et al. Lymphocyte subsets and natural killer cell activity in healthy old people and centenarians. Blood (1993) 82(9):2767-73.

80. Mattoo H, Faulkner M, Kandpal U, Das R, Lewis V, George A, et al. Naive CD4 $\mathrm{T}$ cells from aged mice show enhanced death upon primary activation. Int Immunol (2009) 21(11):1277-89. doi:10.1093/intimm/dxp094

81. van der Geest KS, Abdulahad WH, Tete SM, Lorencetti PG, Horst G, Bos NA, et al. Aging disturbs the balance between effector and regulatory CD4+ T cells. Exp Gerontol (2014) 60:190-6. doi:10.1016/j.exger.2014. 11.005

82. Bruunsgaard H, Pedersen AN, Schroll M, Skinhoj P, Pedersen BK. Proliferative responses of blood mononuclear cells (BMNC) in a cohort of elderly humans: role of lymphocyte phenotype and cytokine production. Clin Exp Immunol (2000) 119(3):433-40. doi:10.1046/j.1365-2249.2000.01146.x

83. Aggarwal S, Gupta S. Increased apoptosis of T cell subsets in aging humans: altered expression of Fas (CD95), Fas ligand, Bcl-2, and Bax. J Immunol (1998) 160(4):1627-37.

84. Aggarwal S, Gollapudi S, Gupta S. Increased TNF-alpha-induced apoptosis in lymphocytes from aged humans: changes in TNF-alpha receptor expression and activation of caspases. J Immunol (1999) 162(4):2154-61.

85. Haynes L, Linton PJ, Eaton SM, Tonkonogy SL, Swain SL. Interleukin 2, but not other common gamma chain-binding cytokines, can reverse the defect in generation of CD4 effector T cells from naive T cells of aged mice. J Exp Med (1999) 190(7):1013-24. doi:10.1084/jem.190.7.1013

86. Lefebvre JS, Maue AC, Eaton SM, Lanthier PA, Tighe M, Haynes L. The aged microenvironment contributes to the age-related functional defects of CD4 T cells in mice. Aging Cell (2012) 11(5):732-40. doi:10.1111/ j.1474-9726.2012.00836.x

87. Maue AC, Eaton SM, Lanthier PA, Sweet KB, Blumerman SL, Haynes L. Proinflammatory adjuvants enhance the cognate helper activity of aged CD4 T cells. J Immunol (2009) 182(10):6129-35. doi:10.4049/jimmunol.0804226

88. Lefebvre JS, Masters AR, Hopkins JW, Haynes L. Age-related impairment of humoral response to influenza is associated with changes in antigen specific T follicular helper cell responses. Sci Rep (2016) 6:25051. doi:10.1038/ srep25051

89. Lages CS, Suffia I, Velilla PA, Huang B, Warshaw G, Hildeman DA, et al. Functional regulatory $\mathrm{T}$ cells accumulate in aged hosts and promote chronic infectious disease reactivation. J Immunol (2008) 181(3):1835-48. doi:10.4049/jimmunol.181.3.1835 
90. Raynor J, Karns R, Almanan M, Li KP, Divanovic S, Chougnet CA, et al. IL-6 and ICOS antagonize Bim and promote regulatory T cell accrual with age. J Immunol (2015) 195(3):944-52. doi:10.4049/jimmunol.1500443

91. Huang MC, Liao JJ, Bonasera S, Longo DL, Goetzl EJ. Nuclear factorkappaB-dependent reversal of aging-induced alterations in T cell cytokines. FASEB J (2008) 22(7):2142-50. doi:10.1096/fj.07-103721

92. Rosenkranz D, Weyer S, Tolosa E, Gaenslen A, Berg D, Leyhe T, et al. Higher frequency of regulatory $\mathrm{T}$ cells in the elderly and increased suppressive activity in neurodegeneration. J Neuroimmunol (2007) 188(1-2):117-27. doi:10.1016/j.jneuroim.2007.05.011

93. Hwang KA, Kim HR, Kang I. Aging and human CD4(+) regulatory T cells. Mech Ageing Dev (2009) 130(8):509-17. doi:10.1016/j.mad.2009.06.003

94. Hogan T, Gossel G, Yates AJ, Seddon B. Temporal fate mapping reveals age-linked heterogeneity in naive T lymphocytes in mice. Proc Natl Acad Sci U S A (2015) 112(50):E6917-26. doi:10.1073/pnas.1517246112

95. Wallace DL, Zhang Y, Ghattas H, Worth A, Irvine A, Bennett AR, et al. Direct measurement of $\mathrm{T}$ cell subset kinetics in vivo in elderly men and women. J Immunol (2004) 173(3):1787-94. doi:10.4049/jimmunol.173.3.1787

96. Naylor K, Li G, Vallejo AN, Lee WW, Koetz K, Bryl E, et al. The influence of age on T cell generation and TCR diversity. J Immunol (2005) 174(11):7446-52. doi:10.4049/jimmunol.174.11.7446

97. Kassiotis G, Zamoyska R, Stockinger B. Involvement of avidity for major histocompatibility complex in homeostasis of naive and memory $\mathrm{T}$ cells. J Exp Med (2003) 197(8):1007-16. doi:10.1084/jem.20021812

98. Kieper WC, Burghardt JT, Surh CD. A role for TCR affinity in regulating naive $\mathrm{T}$ cell homeostasis. J Immunol (2004) 172(1):40-4. doi:10.4049/ jimmunol.172.1.40

99. Rudd BD, Venturi V, Li G, Samadder P, Ertelt JM, Way SS, et al. Nonrandom attrition of the naive $\mathrm{CD} 8+\mathrm{T}$-cell pool with aging governed by T-cell receptor:pMHC interactions. Proc Natl Acad Sci U S A (2011) 108(33):13694-9. doi:10.1073/pnas.1107594108

100. Weng NP. Aging of the immune system: how much can the adaptive immune system adapt? Immunity (2006) 24(5):495-9. doi:10.1016/j.immuni. 2006.05.001

101. Linton PJ, Dorshkind K. Age-related changes in lymphocyte development and function. Nat Immunol (2004) 5(2):133-9. doi:10.1038/ni1033

102. Johnson SA, Cambier JC. Ageing, autoimmunity and arthritis: senescence of the B cell compartment - implications for humoral immunity. Arthritis Res Ther (2004) 6(4):131-9. doi:10.1186/ar1180

103. Frasca D, Landin AM, Riley RL, Blomberg BB. Mechanisms for decreased function of B cells in aged mice and humans. J Immunol (2008) 180(5):2741-6. doi:10.4049/jimmunol.180.5.2741

104. Gibson KL, Wu YC, Barnett Y, Duggan O, Vaughan R, Kondeatis E, et al. B-cell diversity decreases in old age and is correlated with poor health status. Aging Cell (2009) 8(1):18-25. doi:10.1111/j.1474-9726.2008.00443.x

105. Murasko DM, Bernstein ED, Gardner EM, Gross P, Munk G, Dran S, et al. Role of humoral and cell-mediated immunity in protection from influenza disease after immunization of healthy elderly. Exp Gerontol (2002) 37(2-3):427-39. doi:10.1016/S0531-5565(01)00210-8

106. Nicoletti C, Yang X, Cerny J. Repertoire diversity of antibody response to bacterial antigens in aged mice. III. Phosphorylcholine antibody from young and aged mice differ in structure and protective activity against infection with Streptococcus pneumoniae. J Immunol (1993) 150(2):543-9.

107. Frasca D, Landin AM, Lechner SC, Ryan JG, Schwartz R, Riley RL, et al. Aging down-regulates the transcription factor E2A, activation-induced cytidine deaminase, and Ig class switch in human B cells. J Immunol (2008) 180(8):5283-90. doi:10.4049/jimmunol.180.8.5283

108. Speziali E, Santiago AF, Fernandes RM, Vaz NM, Menezes JS, Faria AM. Specific immune responses but not basal functions of $\mathrm{B}$ and $\mathrm{T}$ cells are impaired in aged mice. Cell Immunol (2009) 256(1-2):1-5. doi:10.1016/j. cellimm.2009.01.010

109. Zheng B, Han S, Takahashi Y, Kelsoe G. Immunosenescence and germinal center reaction. Immunol Rev (1997) 160:63-77. doi:10.1111/j.1600-065X. 1997.tb01028.x

110. Frasca D, Van der Put E, Riley RL, Blomberg BB. Reduced Ig class switch in aged mice correlates with decreased E47 and activation-induced cytidine deaminase. J Immunol (2004) 172(4):2155-62. doi:10.4049/jimmunol.172. 4.2155
111. Whisler RL, Grants IS. Age-related alterations in the activation and expression of phosphotyrosine kinases and protein kinase C (PKC) among human B cells. Mech Ageing Dev (1993) 71(1-2):31-46. doi:10.1016/0047-6374(93) 90033-N

112. Dailey RW, Eun SY, Russell CE, Vogel LA. B cells of aged mice show decreased expansion in response to antigen, but are normal in effector function. Cell Immunol (2001) 214(2):99-109. doi:10.1006/cimm.2001.1894

113. Frasca D, Riley RL, Blomberg BB. Effect of age on the immunoglobulin class switch. Crit Rev Immunol (2004) 24(5):297-320. doi:10.1615/ CritRevImmunol.v24.i5.10

114. Frasca D, Van der Put E, Landin AM, Gong D, Riley RL, Blomberg BB. RNA stability of the E2A-encoded transcription factor E47 is lower in splenic activated B cells from aged mice. J Immunol (2005) 175(10):6633-44. doi:10.4049/jimmunol.175.10.6633

115. Kline GH, Hayden TA, Klinman NR. B cell maintenance in aged mice reflects both increased B cell longevity and decreased B cell generation. J Immunol (1999) 162(6):3342-9.

116. Klinman NR, Kline GH. The B-cell biology of aging. Immunol Rev (1997) 160:103-14. doi:10.1111/j.1600-065X.1997.tb01031.x

117. Weksler ME. Changes in the B-cell repertoire with age. Vaccine (2000) 18(16):1624-8. doi:10.1016/S0264-410X(99)00497-1

118. Hao Y, O'Neill P, Naradikian MS, Scholz JL, Cancro MP. A B-cell subset uniquely responsive to innate stimuli accumulates in aged mice. Blood (2011) 118(5):1294-304. doi:10.1182/blood-2011-01-330530

119. Rubtsov AV, Rubtsova K, Fischer A, Meehan RT, Gillis JZ, Kappler JW, et al. Toll-like receptor 7 (TLR7)-driven accumulation of a novel CD11c(+) B-cell population is important for the development of autoimmunity. Blood (2011) 118(5):1305-15. doi:10.1182/blood-2011-01-331462

120. Lee-Chang C, Bodogai M, Moritoh K, Olkhanud PB, Chan AC, Croft M, et al. Accumulation of 4-1BBL+ B cells in the elderly induces the generation of granzyme-B+ CD8+ T cells with potential antitumor activity. Blood (2014) 124(9):1450-9. doi:10.1182/blood-2014-03-563940

121. Naradikian MS, Hao Y, Cancro MP. Age-associated B cells: key mediators of both protective and autoreactive humoral responses. Immunol Rev (2016) 269(1):118-29. doi:10.1111/imr.12380

122. Al-Attar A, Presnell SR, Peterson CA, Thomas DT, Lutz CT. Data correlations between gender, cytomegalovirus infection and $\mathrm{T}$ cells, NK cells, and soluble immune mediators in elderly humans. Data Brief (2016) 8:536-44. doi:10.1016/j.dib.2016.06.006

123. Marttila S, Jylhävä J, Nevalainen T, Nykter M, Jylhä M, Hervonen A, et al. Transcriptional analysis reveals gender-specific changes in the aging of the human immune system. PLoS One (2013) 8(6):e66229. doi:10.1371/journal. pone.0066229

124. Al-Attar A, Presnell SR, Peterson CA, Thomas DT, Lutz CT. The effect of sex on immune cells in healthy aging: elderly women have more robust natural killer lymphocytes than do elderly men. Mech Ageing Dev (2016) 156:25-33. doi:10.1016/j.mad.2016.04.001

125. Yovel G, Shakhar K, Ben-Eliyahu S. The effects of sex, menstrual cycle, and oral contraceptives on the number and activity of natural killer cells. Gynecol Oncol (2001) 81(2):254-62. doi:10.1006/gyno.2001.6153

126. Bain BJ. Ethnic and sex differences in the total and differential white cell count and platelet count. JClin Pathol (1996) 49(8):664-6. doi:10.1136/ jcp.49.8.664

127. Sánchez-Ramón S, Radigan L, Joyce EY, Bard S, Cunningham-Rundles C. Memory B cells in common variable immunodeficiency: clinical associations and sex differences. Clin Immunol (2008) 128(3):314-21. doi:10.1016/j. clim.2008.02.013

128. Warren KJ, Sweeter JM, Pavlik JA, Nelson AJ, Devasure JM, Dickinson JD, et al. Sex differences in activation of lung-related type 2 innate lymphoid cells in experimental asthma. Ann Allergy Asthma Immunol (2017) 118(2):233-4. doi:10.1016/j.anai.2016.11.011

129. Les Laboratoires Servier. Lymphatic system Illustrations (2018) Available from: https://smart.servier.com/ (Accessed: March 15, 2018).

130. Klein SL, Flanagan KL. Sex differences in immune responses. Nat Rev Immunol (2016) 16(10):626-38. doi:10.1038/nri.2016.90

131. Traub S, Demaria O, Chasson L, Serra F, Desnues B, Alexopoulou L. Sex bias in susceptibility to MCMV infection: implication of TLR9. PLoS One (2012) 7(9):e45171. doi:10.1371/journal.pone.0045171 
132. Pisitkun P, Deane JA, Difilippantonio MJ, Tarasenko T, Satterthwaite AB, Bolland S. Autoreactive B cell responses to RNA-related antigens due to TLR7 gene duplication. Science (2006) 312(5780):1669-72. doi:10.1126/ science. 1124978

133. Berghofer B, Frommer T, Haley G, Fink L, Bein G, Hackstein H. TLR7 ligands induce higher IFN-alpha production in females. J Immunol (2006) 177(4):2088-96. doi:10.4049/jimmunol.177.4.2088

134. Da Silva JA. Sex hormones, glucocorticoids and autoimmunity: facts and hypotheses. Ann Rheum Dis (1995) 54(1):6-16. doi:10.1136/ard.54.1.6

135. Fish EN. The X-files in immunity: sex-based differences predispose immune responses. Nat Rev Immunol (2008) 8(9):737-44. doi:10.1038/nri2394

136. Spitzer JA. Gender differences in some host defense mechanisms. Lupus (1999) 8(5):380-3. doi:10.1177/096120339900800510

137. Mondal S, Rai U. Sexual dimorphism in phagocytic activity of wall lizard's splenic macrophages and its control by sex steroids. Gen Comp Endocrinol (1999) 116(2):291-8. doi:10.1006/gcen.1999.7370

138. Weinstein Y, Ran S, Segal S. Sex-associated differences in the regulation of immune responses controlled by the MHC of the mouse. J Immunol (1984) 132(2):656-61.

139. Furman D, Hejblum BP, Simon N, Jojic V, Dekker CL, Thiebaut R, et al. Systems analysis of sex differences reveals an immunosuppressive role for testosterone in the response to influenza vaccination. Proc Natl Acad Sci U S A (2014) 111(2):869-74. doi:10.1073/pnas.1321060111

140. Deguchi K, Kamada M, Irahara M, Maegawa M, Yamamoto S, Ohmoto Y, et al. Postmenopausal changes in production of type 1 and type 2 cytokines and the effects of hormone replacement therapy. Menopause (2001) 8(4):266-73. doi:10.1097/00042192-200107000-00008

141. Kumru S, Godekmerdan A, Yilmaz B. Immune effects of surgical menopause and estrogen replacement therapy in peri-menopausal women. J Reprod Immunol (2004) 63(1):31-8. doi:10.1016/j.jri.2004.02.001

142. Maggio M, Basaria S, Ble A, Lauretani F, Bandinelli S, Ceda GP, et al. Correlation between testosterone and the inflammatory marker soluble interleukin-6 receptor in older men. J Clin Endocrinol Metab (2006) 91(1): 345-7. doi:10.1210/jc.2005-1097

143. Siegel R, Naishadham D, Jemal A. Cancer statistics for Hispanics/Latinos 2012. CA Cancer J Clin (2012) 62:10-29. doi:10.3322/caac.21153

144. Butterworth M, McClellan B, Allansmith M. Influence of sex in immunoglobulin levels. Nature (1967) 214(5094):1224-5. doi:10.1038/2141224a0

145. Klein SL, Huber S. Sex differences in susceptibility to viral infection. In: Klein SL, Roberts CW, editors. Sex Hormones and Immunity to Infection. Berlin: Springer-Verlag (2009) 93-122.

146. Cook IF. Sexual dimorphism of humoral immunity with human vaccines. Vaccine (2008) 26(29-30):3551-5. doi:10.1016/j.vaccine.2008.04.054

147. Klein SL, Jedlicka A, Pekosz A. The Xs and Y of immune responses to viral vaccines. Lancet Infect Dis (2010) 10(5):338-49. doi:10.1016/ S1473-3099(10)70049-9

148. Wikby A, Mansson IA, Johansson B, Strindhall J, Nilsson SE. The immune risk profile is associated with age and gender: findings from three Swedish population studies of individuals 20-100 years of age. Biogerontology (2008) 9(5):299-308. doi:10.1007/s10522-008-9138-6

149. Villacres MC, Longmate J, Auge C, Diamond DJ. Predominant type 1 CMV-specific memory T-helper response in humans: evidence for gender differences in cytokine secretion. Hum Immunol (2004) 65(5):476-85. doi:10.1016/j.humimm.2004.02.021

150. Amadori A, Zamarchi R, De Silvestro G, Forza G, Cavatton G, Danieli GA, et al. Genetic control of the CD4/CD8 T-cell ratio in humans. Nat Med (1995) 1(12):1279-83. doi:10.1038/nm1295-1279

151. Das BR, Bhanushali AA, Khadapkar R, Jeswani KD, Bhavsar M, Dasgupta A. Reference ranges for lymphocyte subsets in adults from western India: influence of sex, age and method of enumeration. Indian J Med Sci (2008) 62(10):397-406. doi:10.4103/0019-5359.42725

152. Strindhall J, Skog M, Ernerudh J, Bengner M, Lofgren S, Matussek A, et al. The inverted CD4/CD8 ratio and associated parameters in 66-year-old individuals: the Swedish HEXA immune study. Age (Dordr) (2013) 35(3):985-91. doi:10.1007/s11357-012-9400-3

153. Lee OJ, Cho YN, Kee SJ, Kim MJ, Jin HM, Lee SJ, et al. Circulating mucosal-associated invariant $\mathrm{T}$ cell levels and their cytokine levels in healthy adults. Exp Gerontol (2014) 49:47-54. doi:10.1016/j.exger.2013. 11.003
154. Hirokawa K, Utsuyama M, Hayashi Y, Kitagawa M, Makinodan T, Fulop T. Slower immune system aging in women versus men in the Japanese population. Immun Ageing (2013) 10(1):19. doi:10.1186/1742-4933-10-19

155. Kovats S, Carreras E, Agrawal H. Sex steroid receptors in immune cells. In: Klein SL, Roberts CW, editors. Sex Hormones and Immunity to Infection. Berlin: Springer-Verlag (2010) 53-92.

156. Perheentupa A, Huhtaniemi I. Aging of the human ovary and testis. Mol Cell Endocrinol (2009) 299(1):2-13. doi:10.1016/j.mce.2008.11.004

157. Bain J. Testosterone and the aging male: to treat or not to treat? Maturitas (2010) 66(1):16-22. doi:10.1016/j.maturitas.2010.01.009

158. Neal-Perry G, Nejat E, Dicken C. The neuroendocrine physiology of female reproductive aging: an update. Maturitas (2010) 67(1):34-8. doi:10.1016/j. maturitas.2010.04.016

159. Giefing-Kröll C, Berger P, Lepperdinger G, Grubeck-Loebenstein B. How sex and age affect immune responses, susceptibility to infections, and response to vaccination. Aging Cell (2015) 14(3):309-21. doi:10.1111/acel.12326

160. Giglio T, Imro MA, Filaci G, Scudeletti M, Puppo F, De Cecco L, et al. Immune cell circulating subsets are affected by gonadal function. Life Sci (1994) 54(18):1305-12. doi:10.1016/0024-3205(94)00508-7

161. Kamada M, Irahara M, Maegawa M, Yasui T, Yamano S, Yamada M, et al. B cell subsets in postmenopausal women and the effect of hormone replacement therapy. Maturitas (2001) 37(3):173-9. doi:10.1016/S0378-5122(00)00180-8

162. Rais M, Wilson RM, Urbanski HF, Messaoudi I. Androgen supplementation improves some but not all aspects of immune senescence in aged male macaques. GeroScience (2017) 39:373-84. doi:10.1007/s11357-017-9979-5

163. Elderman M, Sovran B, Hugenholtz F, Graversen K, Huijskes M, Houtsma E, et al. The effect of age on the intestinal mucus thickness, microbiota composition and immunity in relation to sex in mice. PLoS One (2017) 12(9):e0184274. doi:10.1371/journal.pone.0184274

164. Markle JG, Frank DN, Mortin-Toth S, Robertson CE, Feazel LM, Rolle-Kampczyk U, et al. Sex differences in the gut microbiome drive hormone-dependent regulation of autoimmunity. Science (2013) 339(6123) 1084-8. doi:10.1126/science.1233521

165. Haro C, Rangel-Zúñiga OA, Alcalá-Díaz JF, Gómez-Delgado F, PérezMartínez P, Delgado-Lista J, et al. Intestinal microbiota is influenced by gender and body mass index. PLoS One (2016) 11(5):e0154090. doi:10.1371/ journal.pone.0154090

166. Singh P, Manning SD. Impact of age and sex on the composition and abundance of the intestinal microbiota in individuals with and without enteric infections. Ann Epidemiol (2016) 26(5):380-5. doi:10.1016/j.annepidem. 2016.03.007

167. Kozik AJ, Nakatsu CH, Chun H, Jones-Hall YL. Age, sex, and TNF associated differences in the gut microbiota of mice and their impact on acute TNBS colitis. Exp Mol Pathol (2017) 103(3):311-9. doi:10.1016/j.yexmp.2017.11.014

168. Yurkovetskiy L, Burrows M, Khan AA, Graham L, Volchkov P, Becker L, et al. Gender bias in autoimmunity is influenced by microbiota. Immunity (2013) 39(2):400-12. doi:10.1016/j.immuni.2013.08.013

169. Belkaid Y, Hand TW. Role of the microbiota in immunity and inflammation. Cell (2014) 157(1):121-41. doi:10.1016/j.cell.2014.03.011

170. Gopalakrishnan V, Helmink BA, Spencer CN, Reuben A, Wargo JA. The influence of the gut microbiome on cancer, immunity, and cancer immunotherapy. Cancer Cell (2018) 33(4):570-80. doi:10.1016/j.ccell.2018.03.015

171. Gomez A, Luckey D, Taneja V. The gut microbiome in autoimmunity: sex matters. Clin Immunol (2015) 159(2):154-62. doi:10.1016/j.clim.2015.04.016

172. Bolnick DI, Snowberg LK, Hirsch PE, Lauber CL, Org E, Parks B, et al. Individual diet has sex-dependent effects on vertebrate gut microbiota. Nat Commun (2014) 5:4500. doi:10.1038/ncomms5500

173. Mueller S, Saunier K, Hanisch C, Norin E, Alm L, Midtvedt T, et al. Differences in fecal microbiota in different European study populations in relation to age, gender, and country: a cross-sectional study. Appl Environ Microbiol (2006) 72(2):1027-33. doi:10.1128/AEM.72.2.1027-1033.2006

174. Falsey AR, Treanor JJ, Tornieporth N, Capellan J, Gorse GJ. Randomized, double-blind controlled phase 3 trial comparing the immunogenicity of high-dose and standard-dose influenza vaccine in adults 65 years of age and older. J Infect Dis (2009) 200(2):172-80. doi:10.1086/599790

175. Brandão AP, De Oliveira TC, de Cunto Brandileone MC, Gonçalves JE, Yara TI, Simonsen V. Persistence of antibody response to pneumococcal capsular polysaccharides in vaccinated long term-care residents in Brazil. Vaccine (2004) 23(6):762-8. doi:10.1016/j.vaccine.2004.07.024 
176. Goldblatt D, Southern J, Andrews N, Ashton L, Burbidge P, Woodgate S, et al. The immunogenicity of 7 -valent pneumococcal conjugate vaccine versus 23 -valent polysaccharide vaccine in adults aged $50-80$ years. Clin Infecti Dis (2009) 49(9):1318-25. doi:10.1086/606046

177. Hainz U, Jenewein B, Asch E, Pfeiffer K-P, Berger P, Grubeck-Loebenstein B. Insufficient protection for healthy elderly adults by tetanus and TBE vaccines. Vaccine (2005) 23(25):3232-5. doi:10.1016/j.vaccine.2005.01.085

178. Stark K, Schönfeld C, Barg J, Molz B, Vornwald A, Bienzle U. Seroprevalence and determinants of diphtheria, tetanus and poliomyelitis antibodies among adults in Berlin, Germany. Vaccine (1999) 17(7):844-50. doi:10.1016/ S0264-410X(98)00269-2

179. Marlovits S, Stocker R, Efstratiou A, Broughton K, Kaider A, Vecsei V, et al. Effect on diphtheria immunity of combined tetanus and diphtheria booster vaccination in adults. Eur J Clin Microbiol Infect Dis (2000) 19(7):506-13. doi:10.1007/s100960000305

180. Cook IF. Sex differences in injection site reactions with human vaccines. Hum Vaccin (2009) 5(7):441-9. doi:10.4161/hv.8476

181. Nichol KL, Margolis KL, Lind A, Murdoch M, McFadden R, Hauge M, et al. Side effects associated with influenza vaccination in healthy working adults. A randomized, placebo-controlled trial. Arch Intern Med (1996) 156(14):1546-50. doi:10.1001/archinte.1996.00440130090009

182. Govaert T, Dinant G, Aretz K, Masurel N, Sprenger M, Knottnerus J. Adverse reactions to influenza vaccine in elderly people: randomised double blind placebo controlled trial. BMJ (1993) 307(6910):988-90. doi:10.1136/bmj.307.6910.988

183. Honkanen PO, Keistinen T, Kivelä S-L. Reactions following administration of influenza vaccine alone or with pneumococcal vaccine to the elderly. Arch Intern Med (1996) 156(2):205-8. doi:10.1001/archinte.1996.00440020115015

184. Donalisio MR, Ramalheira RM, Cordeiro R. Eventos adversos após vacinação contra influenza em idosos, Distrito de Campinas, SP, 2000. Rev Soc Bras Med Trop (2003) 36(4):467-71. doi:10.1590/S0037-86822003000400006

185. Couch RB, Winokur P, Brady R, Belshe R, Chen WH, Cate TR, et al. Safety and immunogenicity of a high dosage trivalent influenza vaccine among elderly subjects. Vaccine (2007) 25(44):7656-63. doi:10.1016/j.vaccine.2007.08.042

186. Beyer WP, Palache A, Kerstens R, Masurel N. Gender differences in local and systemic reactions to inactivated influenza vaccine, established by a meta-analysis of fourteen independent studies. Eur J Clin Microbiol Infect Dis (1996) 15(1):65-70. doi:10.1007/BF01586187

187. Engler RJ, Nelson MR, Klote MM, VanRaden MJ, Huang C-Y, Cox NJ, et al. Half-vs full-dose trivalent inactivated influenza vaccine (2004-2005): age, dose, and sex effects on immune responses. Arch Intern Med (2008) 168(22):2405-14. doi:10.1001/archinternmed.2008.513

188. Jackson LA, Austin G, Chen RT, Stout R, DeStefano F, Gorse GJ, et al. Safety and immunogenicity of varying dosages of trivalent inactivated influenza vaccine administered by needle-free jet injectors. Vaccine (2001) 19(32):4703-9. doi:10.1016/S0264-410X(01)00225-0

189. Cook IF, Pond D, Hartel G. Comparative reactogenicity and immunogenicity of 23 valent pneumococcal vaccine administered by intramuscular or subcutaneous injection in elderly adults. Vaccine (2007) 25(25):4767-74. doi:10.1016/j.vaccine.2007.04.017

190. Sočan M, Frelih T, Janet E, Petraš T, Peternelj B. Reactions after pneumococcal vaccine alone or in combination with influenza vaccine. Vaccine (2004) 22(23):3087-91. doi:10.1016/j.vaccine.2004.02.003

191. Hillebrand K, Bricout H, Schulze-Rath R, Schink T, Garbe E. Incidence of herpes zoster and its complications in Germany, 2005-2009. J Infect (2015) 70(2):178-86. doi:10.1016/j.jinf.2014.08.018

192. Gergen PJ, McQuillan GM, Kiely M, Ezzati-Rice TM, Sutter RW, Virella G. A population-based serologic survey of immunity to tetanus in the United States. N Engl J Med (1995) 332(12):761-7. doi:10.1056/NEJM199503233321201

193. White W, Barnes G, Barker E, Gall D, Knight P, Griffith A, et al. Reactions to tetanus toxoid. JHyg (Lond) (1973) 71(02):283-97. doi:10.1017/ S0022172400022750

194. Bayas J, Vilella A, Bertran M, Vidal J, Batalla J, Asenjo M, et al. Immunogenicity and reactogenicity of the adult tetanus-diphtheria vaccine. How many doses are necessary? Epidemiol Infect (2001) 127(03):451-60. doi:10.1017/ S095026880100629X

195. Weinberg GA, Szilagyi PG. Vaccine epidemiology: efficacy, effectiveness, and the translational research roadmap. J Infect Dis (2010) 201(11):1607-10. doi:10.1086/652404
196. Wang CS, Wang ST, Chou P. Efficacy and cost-effectiveness of influenza vaccination of the elderly in a densely populated and unvaccinated community. Vaccine (2002) 20(19-20):2494-9. doi:10.1016/S0264-410X(02)00181-0

197. Vila-Córcoles A, Rodriguez T, de Diego C, Ochoa O, Valdivieso A, Salsench E, et al. Effect of influenza vaccine status on winter mortality in Spanish community-dwelling elderly people during 2002-2005 influenza periods. Vaccine (2007) 25(37):6699-707. doi:10.1016/j.vaccine.2007.07.015

198. Fleming D, Watson J, Nicholas S, Smith G, Swan A. Study of the effectiveness of influenza vaccination in the elderly in the epidemic of 1989-90 using a general practice database. Epidemiol Infect (1995) 115(3):581-9. doi:10.1017/ S095026880005874X

199. Nichol KL, Nordin JD, Nelson DB, Mullooly JP, Hak E. Effectiveness of influenza vaccine in the community-dwelling elderly. N Engl J Med (2007) 357(14):1373-81. doi:10.1056/NEJMoa070844

200. Nichol K, Margolis K, Wuorenma J, Von Sternberg T. The efficacy and cost effectiveness of vaccination against influenza among elderly persons living in the community. N Engl J Med (1994) 331(12):778-84. doi:10.1056/ NEJM199409223311206

201. Soneji S, Metlay J. Mortality reductions for older adults differ by race/ethnicity and gender since the introduction of adult and pediatric pneumococcal vaccines. Public Health Rep (2011) 126(2):259. doi:10.1177/003335491112600217

202. Wiemken TL, Carrico RM, Klein SL, Jonsson CB, Peyrani P, Kelley RR, et al. The effectiveness of the polysaccharide pneumococcal vaccine for the prevention of hospitalizations due to Streptococcus pneumoniae community-acquired pneumonia in the elderly differs between the sexes: results from the Community-Acquired Pneumonia Organization (CAPO) international cohort study. Vaccine (2014) 32(19):2198-203. doi:10.1016/j. vaccine.2014.02.048

203. Vadasz Z, Haj T, Kessel A, Toubi E. Age-related autoimmunity. BMC Med (2013) 11:94. doi:10.1186/1741-7015-11-94

204. Rosenblum MD, Remedios KA, Abbas AK. Mechanisms of human autoimmunity. J Clin Invest (2015) 125(6):2228-33. doi:10.1172/JCI78088

205. Cooper GS, Stroehla BC. The epidemiology of autoimmune diseases. Autoimmun Rev (2003) 2(3):119-25. doi:10.1016/S1568-9972(03)00006-5

206. Kotzin BL. Systemic lupus erythematosus. Cell (1996) 85(3):303-6. doi:10.1016/ S0092-8674(00)81108-3

207. Pandit L, Asgari N, Apiwattanakul M, Palace J, Paul F, Leite MI, et al. Demographic and clinical features of neuromyelitis optica: a review. Mult Scler (2015) 21(7):845-53. doi:10.1177/1352458515572406

208. Quek AM, McKeon A, Lennon VA, Mandrekar JN, Iorio R, Jiao Y, et al. Effects of age and sex on aquaporin-4 autoimmunity. Arch Neurol (2012) 69(8):1039-43. doi:10.1001/archneurol.2012.249

209. Steen VD, Oddis CV, Conte CG, Janoski J, Casterline GZ, Medsger TA Jr. Incidence of systemic sclerosis in Allegheny county, Pennsylvania. A twentyyear study of hospital-diagnosed cases, 1963-1982. Arthritis Rheum (1997) 40(3):441-5. doi:10.1002/art.1780400309

210. Linos A, Worthington JW, O'Fallon WM, Kurland LT. The epidemiology of rheumatoid arthritis in Rochester, Minnesota: a study of incidence, prevalence, and mortality. Am J Epidemiol (1980) 111(1):87-98. doi:10.1093/ oxfordjournals.aje.a112878

211. Weyand CM, Goronzy JJ. Giant-cell arteritis and polymyalgia rheumatica. N Engl J Med (2014) 371(17):1653. doi:10.1056/NEJMcp1214825

212. Ostan R, Monti D, Gueresi P, Bussolotto M, Franceschi C, Baggio G. Gender, aging and longevity in humans: an update of an intriguing/neglected scenario paving the way to a gender-specific medicine. Clin Sci (Lond) (2016) 130(19):1711-25. doi:10.1042/CS20160004

213. Borras C, Sastre J, Garcia-Sala D, Lloret A, Pallardo FV, Vina J. Mitochondria from females exhibit higher antioxidant gene expression and lower oxidative damage than males. Free Radic Biol Med (2003) 34(5):546-52. doi:10.1016/ S0891-5849(02)01356-4

214. Vina J, Borras C, Gambini J, Sastre J, Pallardo FV. Why females live longer than males? Importance of the upregulation of longevity-associated genes by oestrogenic compounds. FEBS Lett (2005) 579(12):2541-5. doi:10.1016/j. febslet.2005.03.090

215. Engelmann F, Rivera A, Park B, Messerle-Forbes M, Jensen JT, Messaoudi I. Impact of estrogen therapy on lymphocyte homeostasis and the response to seasonal influenza vaccine in post-menopausal women. PLoS One (2016) 11(2):e0149045. doi:10.1371/journal.pone.0149045 
216. Zhang J, Chen X, Zhang S, Zhou G, Xia X, Lu L. Effects of transdermal estrogen therapy on expressions of estrogen receptors and T-lymphocyte apoptosis in surgically menopausal women. Cell Mol Immunol (2009) 6(4):277-83. doi:10.1038/cmi.2009.37

217. Schulze-Koops H. Lymphopenia and autoimmune diseases. Arthritis Res Ther (2004) 6(4):178-80. doi:10.1186/ar1208

218. Viguier M, Fouere S, de la Salmoniere P, Rabian C, Lebbe C, Dubertret L, et al. Peripheral blood lymphocyte subset counts in patients with dermatomyositis: clinical correlations and changes following therapy. Medicine (Baltimore) (2003) 82(2):82-6. doi:10.1097/00005792-200303000-00002

219. Iannone F, Cauli A, Yanni G, Kingsley GH, Isenberg DA, Corrigall V, et al. T-lymphocyte immunophenotyping in polymyositis and dermatomyositis. $\mathrm{Br}$ J Rheumatol (1996) 35(9):839-45. doi:10.1093/rheumatology/35. 9.839

220. Kirtava Z, Blomberg J, Bredberg A, Henriksson G, Jacobsson L, Manthorpe R. CD4+ T-lymphocytopenia without HIV infection: increased prevalence among patients with primary Sjogren's syndrome. Clin Exp Rheumatol (1995) 13(5):609-16.

221. Mandl T, Bredberg A, Jacobsson LT, Manthorpe R, Henriksson G. CD4+ T-lymphocytopenia - a frequent finding in anti-SSA antibody seropositive patients with primary Sjogren's syndrome. J Rheumatol (2004) 31(4):726-8.

222. Kaaba SA, Al-Harbi SA. Abnormal lymphocyte subsets in Kuwaiti patients with type-1 insulin-dependent diabetes mellitus and their first-degree relatives. Immunol Lett (1995) 47(3):209-13. doi:10.1016/0165-2478(95) 00088-5

223. Brandt L, Stenstam M. Letter: subnormal lymphocyte-counts in adult coeliac disease. Lancet (1975) 1(7913):978-9. doi:10.1016/S0140-6736(75)92041-3

224. Heimann TM, Bolnick K, Aufses AH Jr. Prognostic significance of severe preoperative lymphopenia in patients with Crohn's disease. Ann Surg (1986) 203(2):132-5. doi:10.1097/00000658-198602000-00004

225. Goronzy JJ, Li G, Yang Z, Weyand CM. The Janus head of T cell aging autoimmunity and immunodeficiency. Front Immunol (2013) 4:131. doi:10.3389/fimmu.2013.00131

226. Koetz K, Bryl E, Spickschen K, O’Fallon WM, Goronzy JJ, Weyand CM. T cell homeostasis in patients with rheumatoid arthritis. Proc Natl Acad Sci U S A (2000) 97(16):9203-8. doi:10.1073/pnas.97.16.9203

227. Wagner UG, Koetz K, Weyand CM, Goronzy JJ. Perturbation of the T cell repertoire in rheumatoid arthritis. Proc Natl Acad Sci U S A (1998) 95(24):14447-52. doi:10.1073/pnas.95.24.14447

228. Shao L, Fujii H, Colmegna I, Oishi H, Goronzy JJ, Weyand CM. Deficiency of the DNA repair enzyme ATM in rheumatoid arthritis. J Exp Med (2009) 206(6):1435-49. doi:10.1084/jem.20082251

229. Martens PB, Goronzy JJ, Schaid D, Weyand CM. Expansion of unusual CD4+ T cells in severe rheumatoid arthritis. Arthritis Rheum (1997) 40(6):1106-14. doi:10.1002/art.1780400615

230. Goronzy JJ, Matteson EL, Fulbright JW, Warrington KJ, Chang-Miller A, Hunder GG, et al. Prognostic markers of radiographic progression in early rheumatoid arthritis. Arthritis Rheum (2004) 50(1):43-54. doi:10.1002/ art.11445

231. Komocsi A, Lamprecht P, Csernok E, Mueller A, Holl-Ulrich K, Seitzer U, et al. Peripheral blood and granuloma CD4(+)CD28(-) T cells are a major source of interferon-gamma and tumor necrosis factor-alpha in Wegener's granulomatosis. Am J Pathol (2002) 160(5):1717-24. doi:10.1016/ S0002-9440(10)61118-2

232. McKinney EF, Lyons PA, Carr EJ, Hollis JL, Jayne DR, Willcocks LC, et al. A CD8+ T cell transcription signature predicts prognosis in autoimmune disease. Nat Med (2010) 16(5):586-91. doi:10.1038/nm.2130

233. Jemal A, Siegel R, Ward E, Hao YP, Xu JQ, Thun MJ. Cancer statistics, 2009. CA Cancer J Clin (2009) 59(4):225-49. doi:10.3322/caac.20006

234. Kanapuru B, Posani K, Muller D, Ershler WB. Decreased cancer prevalence in the nursing home. J Am Geriatr Soc (2008) 56(11). doi:10.1111/ j.1532-5415.2008.01864.x

235. Stanta G, Campagner L, Cavalieri F, Giarelli L. Cancer of the oldest old - what we have learned from autopsy studies. Clin Geriatr Med (1997) 13(1):55.

236. Ershler WB, Longo DL. Aging and cancer: issues of basic and clinical science. J Natl Cancer Inst (1997) 89(20):1489-97. doi:10.1093/jnci/89.20.1489

237. Diab SG, Elledge RM, Clark GM. Tumor characteristics and clinical outcome of elderly women with breast cancer. J Natl Cancer Inst (2000) 92(7):550-6. doi:10.1093/jnci/92.7.550
238. Jedroszka D, Orzechowska M, Hamouz R, Gorniak K, Bednarek AK. Markers of epithelial-to-mesenchymal transition reflect tumor biology according to patient age and Gleason score in prostate cancer. PLoS One (2017) 12(12):e0188842. doi:10.1371/journal.pone.0188842

239. Shariat SF, Sfakianos JP, Droller MJ, Karakiewicz PI, Meryn S, Bochner BH. The effect of age and gender on bladder cancer: a critical review of the literature. BJU Int (2010) 105(3):300-8. doi:10.1111/j.1464-410X.2009. 09076.x

240. Ferrara F, Schiffer CA. Acute myeloid leukaemia in adults. Lancet (2013) 381(9865):484-95. doi:10.1016/S0140-6736(12)61727-9

241. Chian CF, Hwang YT, Terng HJ, Lee SC, Chao TY, Chang H, et al. Panels of tumor-derived RNA markers in peripheral blood of patients with nonsmall cell lung cancer: their dependence on age, gender and clinical stages. Oncotarget (2016) 7(31):50582-95. doi:10.18632/oncotarget.10558

242. Snaebjornsson P, Jonasson L, Jonsson T, Moller PH, Theodors A, Jonasson JG. Colon cancer in Iceland-a nationwide comparative study on various pathology parameters with respect to right and left tumor location and patients age. Int J Cancer (2010) 127(11):2645-53. doi:10.1002/ijc.25258

243. Cook MB, Dawsey SM, Freedman ND, Inskip PD, Wichner SM, Quraishi SM, et al. Sex disparities in cancer incidence by period and age. Cancer Epidemiol Biomarkers Prev (2009) 18(4):1174-82. doi:10.1158/1055-9965.EPI-08-1118

244. Cook MB, McGlynn KA, Devesa SS, Freedman ND, Anderson WF. Sex disparities in cancer mortality and survival. Cancer Epidemiol Biomarkers Prev (2011) 20(8):1629-37. doi:10.1158/1055-9965.EPI-11-0246

245. Siegel RL, Miller KD, Jemal A. Cancer statistics, 2018. CA Cancer J Clin (2018) 68(1):7-30. doi:10.3322/caac.21442

246. Purim O, Gordon N, Brenner B. Cancer of the colon and rectum: potential effects of sex-age interactions on incidence and outcome. Med Sci Monit (2013) 19:203-9. doi:10.12659/MSM.883842

247. Yang Y, Li T, Nielsen ME. Aging and cancer mortality: dynamics of change and sex differences. Exp Gerontol (2012) 47(9):695-705. doi:10.1016/j. exger.2012.06.009

248. Yang Y, Kozloski M. Sex differences in age trajectories of physiological dysregulation: inflammation, metabolic syndrome, and allostatic load. J Gerontol A Biol Sci Med Sci (2011) 66(5):493-500. doi:10.1093/gerona/glr003

249. Barzi A, Lenz AM, Labonte MJ, Lenz HJ. Molecular pathways: estrogen pathway in colorectal cancer. Clin Cancer Res (2013) 19(21):5842-8. doi:10.1158/ 1078-0432.CCR-13-0325

250. Caiazza F, Ryan EJ, Doherty G, Winter DC, Sheahan K. Estrogen receptors and their implications in colorectal carcinogenesis. Front Oncol (2015) 5:19. doi:10.3389/fonc.2015.00019

251. DePinho RA. The age of cancer. Nature (2000) 408(6809):248-54. doi:10.1038/ 35041694

252. de Martel C, Franceschi S. Infections and cancer: established associations and new hypotheses. Crit Rev Oncol Hematol (2009) 70(3):183-94. doi:10.1016/j. critrevonc.2008.07.021

253. Takahashi H, Ogata H, Nishigaki R, Broide DH, Karin M. Tobacco smoke promotes lung tumorigenesis by triggering IKKbeta- and JNK1-dependent inflammation. Cancer Cell (2010) 17(1):89-97. doi:10.1016/j.ccr.2009.12.008

254. Park EJ, Lee JH, Yu GY, He G, Ali SR, Holzer RG, et al. Dietary and genetic obesity promote liver inflammation and tumorigenesis by enhancing IL- 6 and TNF expression. Cell (2010) 140(2):197-208. doi:10.1016/j.cell.2009.12.052

255. Khasawneh J, Schulz MD, Walch A, Rozman J, Hrabe de Angelis M, Klingenspor $\mathrm{M}$, et al. Inflammation and mitochondrial fatty acid betaoxidation link obesity to early tumor promotion. Proc Natl Acad Sci U S A (2009) 106(9):3354-9. doi:10.1073/pnas.0802864106

256. Pal SK, Hurria A. Impact of age, sex, and comorbidity on cancer therapy and disease progression. J Clin Oncol (2010) 28(26):4086-93. doi:10.1200/ JCO.2009.27.0579

257. Mirandola L, Wade R, Verma R, Pena C, Hosiriluck N, Figueroa JA, et al. Sexdriven differences in immunological responses: challenges and opportunities for the immunotherapies of the third millennium. Int Rev Immunol (2015) 34(2):134-42. doi:10.3109/08830185.2015.1018417

258. Motzer RJ, Escudier B, McDermott DF, George S, Hammers HJ, Srinivas S, et al. Nivolumab versus everolimus in advanced renal-cell carcinoma. $N$ Engl J Med (2015) 373(19):1803-13. doi:10.1056/NEJMoa1510665

259. Hodi FS. Improved survival with ipilimumab in patients with metastatic melanoma (vol 363, pg 711, 2010). N Engl J Med (2010) 363(13):1290. doi:10.1056/NEJMx100063 
260. Robert C, Long GV, Brady B, Dutriaux C, Maio M, Mortier L, et al. Nivolumab in previously untreated melanoma without BRAF mutation. $N$ Engl J Med (2015) 372(4):320-30. doi:10.1056/NEJMoa1412082

261. Rosenberg JE, Hoffman-Censits J, Powles T, van der Heijden MS, Balar AV, Necchi A, et al. Atezolizumab in patients with locally advanced and metastatic urothelial carcinoma who have progressed following treatment with platinum-based chemotherapy: a single-arm, multicentre, phase 2 trial. Lancet (2016) 387(10031):1909-20. doi:10.1016/S0140-6736(16) 00561-4

262. Lin PY, Sun LS, Thibodeaux SR, Ludwig SM, Vadlamudi RK, Hurez VJ, et al. B7-H1-dependent sex-related differences in tumor immunity and immunotherapy responses. J Immunol (2010) 185(5):2747-53. doi:10.4049/ jimmunol.1000496

263. Patel J, Crawford JM. Microbiota-regulated outcomes of human cancer immunotherapy via the PD-1/PD-L1 axis. Biochemistry (2018) 57(6):901-3. doi:10.1021/acs.biochem.7b01249

264. Nishijima TF, Muss HB, Shachar SS, Moschos SJ. Comparison of efficacy of immune checkpoint inhibitors (ICIs) between younger and older patients: a systematic review and meta-analysis. Cancer Treat Rev (2016) 45:30-7. doi:10.1016/j.ctrv.2016.02.006

265. Ferrara R, Mezquita L, Auclin E, Chaput N, Besse B. Immunosenescence and immunecheckpoint inhibitors in non-small cell lung cancer patients: does age really matter? Cancer Treat Rev (2017) 60:60-8. doi:10.1016/j. ctrv.2017.08.003
266. Landre T, Taleb C, Nicolas P, Guetz GD. Is there a clinical benefit of anti-PD-1 in patients older than 75 years with previously treated solid tumour? J Clin Oncol (2016) 34(15):3070. doi:10.1200/JCO.2016.34.15_suppl.3070

267. Champiat S, Dercle L, Ammari S, Massard C, Hollebecque A, Postel-Vinay S, et al. Hyperprogressive disease is a new pattern of progression in cancer patients treated by anti-PD-1/PD-L1. Clin Cancer Res (2017) 23(8):1920-8. doi:10.1158/1078-0432.CCR-16-1741

268. Bouchlaka MN, Murphy WJ. Impact of aging in cancer immunotherapy the importance of using accurate preclinical models. Oncoimmunology (2013) 2(12):e27186. doi:10.4161/onci.27186

269. Clayton JA. Applying the new SABV (sex as a biological variable) policy to research and clinical care. Physiol Behav (2018) 187:2-5. doi:10.1016/j. physbeh.2017.08.012

Conflict of Interest Statement: The authors declare that the research was conducted in the absence of any commercial or financial relationships that could be construed as a potential conflict of interest.

Copyright (c) 2018 Gubbels Bupp, Potluri, Fink and Klein. This is an open-access article distributed under the terms of the Creative Commons Attribution License (CC BY). The use, distribution or reproduction in other forums is permitted, provided the original author(s) and the copyright owner are credited and that the original publication in this journal is cited, in accordance with accepted academic practice. No use, distribution or reproduction is permitted which does not comply with these terms. 